\title{
Do minimum wages affect employment? Evidence from the manufacturing sector in Indonesia
}

\author{
Ximena Del Carpio ${ }^{1}$, Ha Nguyen ${ }^{2}$, Laura Pabon ${ }^{1}$ and Liang Choon Wang ${ }^{3^{*}}$
}

\author{
* Correspondence: \\ Liang.C.Wang@monash.edu \\ ${ }^{3}$ Monash University, Melbourne, \\ Australia \\ Full list of author information is \\ available at the end of the article
}

\begin{abstract}
This paper investigates the impact of minimum wages on employment and wages in Indonesian manufacturing firms between 1993 and 2006. It shows that within firms, the employment effects of minimum wage hikes is negative. It finds significant, negative employment effects of minimum wages among small firms and for non-production, less-educated and female workers. The paper also finds that minimum wages are more correlated with small firms' average wages than large firms', suggesting that minimum wages are more binding in small firms.
\end{abstract}

Jel codes: J08, J16, J20, J31, L60

Keywords: Minimum wages; Employment; Manufacturing; Gender

\section{Introduction}

Most countries around the world have some forms of minimum wages. Policymakers have often argued that rises in minimum wages lift the earnings of low-income workers, and therefore can be used as a tool to reduce poverty and inequality. In some situations (e.g. with monopsonistic firms), a moderate rise in minimum wages can increase the earnings of low-income workers without causing job losses. Some also argue that wage increases can improve workers' productivity (Levine, 1992; Raff and Summers, 1987) because they lead to increases in work effort, reductions in job turnover and more on-the-job training (Katz, 1987). However, some empirical findings have shown that higher minimum wages lead to lower employment.

Theoretically, whether changes in minimum wages lead to higher employment or job losses depends on where existing wages are set relative to workers' marginal product of labor (MPL). If existing wages are set much below the MPL, as in the case of a monopsonistic firm, a moderate increase in minimum wages can benefit workers without leading to job losses, because the firm still profits from hiring workers, even at a higher wage rate (Rebitzer and Taylor, 1995). On the other hand, in the case of a competitive labor market where equilibrium wages equal the MPL, a minimum wage increase will lead to job losses.

Past literature on minimum wages tends to focus on youth workers and the fast-food industry in developed countries, where minimum wages matter most. As many developing countries are considering adopting minimum wage laws or reforming their

(c) 2015 Del Carpio et al. Open Access This article is distributed under the terms of the Creative Commons Attribution 4.0 International License (http://creativecommons.org/licenses/by/4.0/), which permits unrestricted use, distribution, and reproduction in any medium, provided you give appropriate credit to the original author(s) and the source, provide a link to the Creative Commons license, and indicate if changes were made. 
existing minimum wage systems, it is important to investigate whether minimum wage changes affect employment in a developing country context. The labor market conditions in developing countries are fairly different to those in developed countries. They are typically more segmented, filled with less educated labor, characterized by a high ratio of male-to-female workers, and dominated by small and informal firms. Changes in minimum wages in a developing country can potentially lead to significant heterogeneous effects on a large fraction of the labor force.

This paper uses firm-level data from the Indonesia industry survey (SI) to investigate the impact of minimum wages on employment and firm average wages in the manufacturing sector, differentiating between the effects on workers by production ${ }^{1}$ and nonproduction type, education level, and gender. One may expect the presence of differential wage and employment effects on different types of firms and workers. Yet, there is limited evidence of whether differential effects are present in the manufacturing sector, which typically takes a large share of formal sector employment among poorer countries. Understanding how minimum wage changes affect different types of workers not only informs policymakers regarding the extent of market power that firms may have and the potential social cost of minimum wage laws, it also provides policymakers information on whether additional policy options are needed to assist specific groups when a uniform minimum wage is introduced.

Indonesian is particularly appropriate for the study of the impacts of minimum wage changes on wages and employment in manufacturing by types of workers and firms, as Indonesia has a long history of minimum wage law and has substantial variations of minimum wage changes over time and across provinces. Furthermore, Indonesia's manufacturing census data have broad coverage, track firms over time and contain a wide range of detailed information. This data advantage permits us to perform firm fixed effects regressions to estimate the impacts of minimum wage changes. The use of firm fixed effects regressions helps reduce the potential endogeniety bias that the Indonesian central and provincial governments set provincial minimum wage changes taking into consideration the labor market conditions of provinces. The use of firmlevel fixed effects potentially removes unobserved factors that jointly influence employment in the province and the level of the minimum wages and exploits only variation in employment within firms. We will come back to this point more carefully in the methodology section.

We also show heterogeneous effects of minimum wage changes on employment: the employment effects of minimum wages are significant and negative in small firms and among less educated workers, but not in large firms and among workers with high school education and above. These findings are consistent with the theoretical predictions that small firms and less educated workers have little market power and are more responsive to minimum wage changes. We also find that when minimum wages are raised, job losses are more severe for non-production workers. Non-production employment is more adversely affected by increases in minimum wages perhaps because wages for non-production workers are closer to their MPL. This might be the case because firms tend have less market power in competing for low-skilled non-production workers, who can work in most industries. The analysis also yields clear gender differentiated effects of minimum wages: most of the non-production job losses are experienced by female workers. Lastly, the paper also finds that minimum wages are more 
correlated with average wages in small firms than in large firms. This indicates that wages in small firms are more binding, and an increase in minimum wages helps to increase the average wages in small firms.

\section{Literature review}

There is an extensive literature on the impact of minimum wages on employment. ${ }^{2}$ Earlier studies in the United States provide evidence on positive or no effect of minimum wage increases on employment. For example, Katz and Krueger (1992) find that employment in Texas fast food industry increased following the Federal minimum wage hike in 1991 and argue that the result is consistent with fast food restaurants having monopsonistic power. Card and Krueger (1994) exploit a differences-in-differences approach to examine the effect of the minimum wage increase in 1992 on employment in fast food restaurants in the state of New Jersey relatively to those in the neighboring state of Pennsylvania. They find no effect of the minimum wage hike on employment. As the restaurants surveyed are near the state border and facing similar economic conditions, except the change in the minimum wage, unobserved economic conditions affecting both employment and minimum wage laws are differenced out from the estimated effect.

More recent US evidence indicates a small negative effect of minimum wage changes on employment. Neumark and Wascher (2000) reanalyze Card and Krueger's (1994) seminal work using payroll data and show a small decrease in employment in New Jersey relative to Pennsylvania after the 1992 minimum wage increase. Similarly, the study by Burkhauser et al. (2000) reassess the sensitivity of US studies on the effects of minimum wages on employment that rely on state-level panel data and show significant and modest negative effects of minimum wages on teenage employment. In particular, they demonstrate that past findings on the insignificant effect of minimum wages on employment are sensitive to the inclusion of year fixed effects, which captures the variation in the federal minimum wage and eliminates virtually all of the variation in the minimum wage changes. Past US studies highlight the importance to control for unobserved economic conditions affecting both employment and minimum wage changes, to find variation in minimum wage changes at the sub-national level, and to use relatively high quality data to minimize measurement errors.

Recent work from Dube et al. (2010) argue that past research based on cross-state data is flawed because it does not control for heterogeneities in employment trends, leading to downward biases in the estimates. By comparing contiguous county pairs in the United States, the authors find no detrimental employment effect of the minimum wage. These findings were criticized by Neumark et al. $(2014,2015)$ in their most recent work, who demonstrated that their approach eliminates valid sources of identifying information and lead to incorrect conclusions. Neumark et al. (2014) confirm previous findings from the literature that finds strong disemployment effect among the least skilled workers.

There is a growing volume of empirical studies examining the impacts of minimum wages on employment in developing countries. The evidence tends to indicate negative effects of minimum wage hikes on employment, especially in Latin American countries where the minimum wage level is high relative to the overall wage distribution (Kristensen and Cunningham, 2006). Bell (1997) finds negative impacts of minimum wage 
rises in Colombia, where the minimum wage was close to the average wage, and no impacts in Mexico, where the minimum wage was way below the market clearing. Maloney and Nunez (2004) find a negative employment effect in both formal and self-employed sectors in Colombia. Gindling and Terrell (2007) also report a negative impact on employment in the formal sector in Costa Rica. Similarly, Nguyen (2010) finds that minimum wage increases led to a decrease in formal employment among low-wage formal sector workers in Vietnam.

The issue of minimum wages in Indonesia has also received considerable attention. Rama (2001) uses repeated cross-section of labor force surveys (Sakernas) to create province-level panel data and assess the impact of minimum wages on employment. He finds a negative employment effect for small firms (those with less than 20 workers) but a positive effect for medium-sized and large ones. Islam and Nazara (2000), Suryahadi et al. (2003), and Pratomo (2011) also use Sakernas to generate province-level panel data and find negative effects of minimum wages on employment. For instance, using 1988-1999 data, Suryahadi et al. (2003) estimated the elasticity of employment to minimum wages to be roughly -0.11 . However, since central and provincial governments set minimum wages taken into consideration the labor market conditions of provinces, estimates based on province-level panel data are likely to suffer from the endogeneity bias discussed above. ${ }^{3}$ More recently, Magruder (2011) use district-level panel data to implement a difference in spatial differences estimation strategy to address the potential endogeneity bias of district fixed effects analysis. He shows positive effects of the rise in minimum wages on employment in some sectors-though not in tradable manufacturing-in Indonesia in the early 1990s.

Recent studies use firm data to study the relationship between wages and employment in Indonesia. Alatas and Cameron (2008) adopt Card and Krueger (1994) differences-indifferences approach to study the effects of minimum wage changes between 1990 and 1996 on the employment of production workers in clothing, textiles, footwear and leather firms in greater Jakarta, potentially addresses the problems associated with the use of province fixed effects regressions. They find a negative employment impact of minimum wages on production workers in small firms, with an elasticity estimate in the range of -0.31 to -0.54 , but not in large firms. Harrison and Scorse (2010) examine the impact of antisweatshop campaigns on real wage increases in foreign-owned, exporting firms in textiles, footwear and apparel sectors and find that a $10 \%$ increase in real minimum wages reduces production worker employment by $1.2 \%$, on average. They also find reduced investment, falling profits, and increased probability of going out of business (at least in the formal sector) for smaller firms, but not for large firms. Hallward-Driemeier et al. (2010) use both firm level and labor force data to show that minimum wage increases reduce gender wage gaps for workers who completed junior high school, but that the gap worsens for workers who did not complete primary school.

This paper extends existing literature on the effects of minimum wage changes on employment. By focusing on both production workers and non-production workers, this paper sheds light on issues of policy significance. There is a perception that non-production workers are unaffected by minimum wage changes because they are typically highly-skilled and highly paid workers, such as managers and researchers, whose wages are significantly above the minimum wage. For that reason, the impact of minimum wages on them receives little analysis. However, in reality, a significant portion of non-production workers in the manufacturing sector actually have low education and perform mainly basic tasks. 
Moreover, although non-production workers account for a smaller fraction of the manufacturing labor force, they do account for a much larger fraction in the service sector (and hence in the entire economy), thus making the findings from this paper relevant to the economy as a whole. Third, the analysis on employment of workers by educational attainment and gender informs policymakers who set minimum wage levels with the objective to benefit poorer, often low skilled workers.

One caveat worth highlighting is that by looking at manufacturing firms, this paper focuses on formal manufacturing employment, and not on employment in the informal sector, which accounts for approximately $63 \%$ of the employed workforce in Indonesia (Indonesia Job Reports, 2010). Previous studies show that indeed, workers who lose their formal employment do not necessarily become unemployed but rather they are likely to go into the informal sector (either in self-employment or working in an informal firm) (Loayza et al. 2005; Perry et al., 2007; Nguyen 2010). In Indonesia, there are potentially labor movements and other types of interactions between formal and informal sectors. For instance, using district-level data, Comola and de Mello (2011) find that an increase in minimum wages is associated with job losses in the formal sector and job gains in the informal sector. ${ }^{4}$ A second caveat is that the analysis does not take into account exiting firms, thus potentially underestimating the negative impact of minimum wages. Similarly, we do not take into account new or entering firms, and hence the results do not fully reflect any "multiplier" effects that minimum wage increases can generate in the labor market. The multiplier effect refers to the possibility that with higher wages brought about by the minimum wage rise will translate into higher income and higher purchasing power for workers benefited. Thus, the increase can generate higher demand for other goods and services (Magruder, 2011). Because the added employment of new firms is not captured in the panel regression framework, the multiplier effect cannot be entirely captured in this analysis.

\section{Context and the minimum wage institution}

Indonesia is the world's fourth most populous country with a population of 238 million. It is also the largest economy in South East Asia, the world's 18th largest by nominal gross domestic product (GDP), and a member of G-20 major economies. Despite its on-going economic growth, Indonesia is still considered a lower middle income country, according to the World Bank classification, and has nominal GDP per capita of US\$ 2945 in 2010.

Men are largely overrepresented in the Indonesian labor force. Female labor participation in 2009 is 52 percent, and women are disproportionately represented amongst the lowest paid in Indonesia (Cuevas et al. 2009). The Indonesian workforce is increasingly becoming more educated, but is still relatively less so compared to neighboring countries (World Bank, 2010). For example, Indonesia's overall net secondary enrollment rate was 59 percent in 2006, compared to 61 percent in Vietnam in 2000, 69 percent in Malaysia in 2005, and 71 percent in Thailand in 2006. Similarly, its tertiary enrollment rate is also low by regional standards. In the manufacturing sector, the focus of this paper, the vast majority of the workforce only has at most senior high school education (Indonesia Industry Survey).

The minimum wage legislation in Indonesia was first introduced in the early 1970s for those working in mainly urban areas. According to the 2003 Law on Manpower Affairs 
regulation, minimum wages were established solely to meet the adequate living standard needs of a single worker, and the adequate living standard should be derived from a yearly survey conducted at a provincial level. ${ }^{5}$ The law also establishes, in general terms, that when defining the minimum wage, consideration should be given to productivity and economic growth, as well as to the condition of the labor market, the level of economic development, income per capita, and the capacity to pay and sustainability of employers.

Different minimum wages are set for different provinces to take into account their differences in living costs. Most provinces had just one level of minimum wage, with very few exceptions. Some provinces have different minimum wages set for different districts, or different sectors of the economy. In our econometric analysis we drop the provinces with multiple minimum wages. Until the end of 2000, provincial minimum wages were established centrally by a decree issued by the Minister of Manpower. To determine minimum wage levels, the minister received recommendations from provincial governors, who in turn took advice from provincial councils, made up from representatives of employees, employers and the government. In practice, employee and employer representatives were usually government appointees (Suryahadi et al. 2003). Since 2001, the setting of minimum wage levels was transferred to governors and some cases mayors, who also receive recommendations from councils in their respective areas.

There is substantial variation in minimum wage levels across provinces and over time. For example, Fig. 1 shows normalized real minimum wages across 33 Indonesia's provinces in $2006 .{ }^{6}$ Note that the real minimum wages are calculated as the nominal wages divided by provincial CPI, hence they already reflect provinces' different living costs. Nevertheless, the differences between the real minimum wages across provinces remain large; for instance, the level in Jakarta, the capital and largest economic center, is twice as high as the level in East Java.

Minimum wages in Indonesia also vary markedly over time. Figure 1 shows the evolution of nominal and real minimum wages in Jakarta from 1993 to 2006. The interest in using minimum wages as an instrument to affect workers welfare grew over time, and in late 1980s, after pressure from international groups about low wages, workers

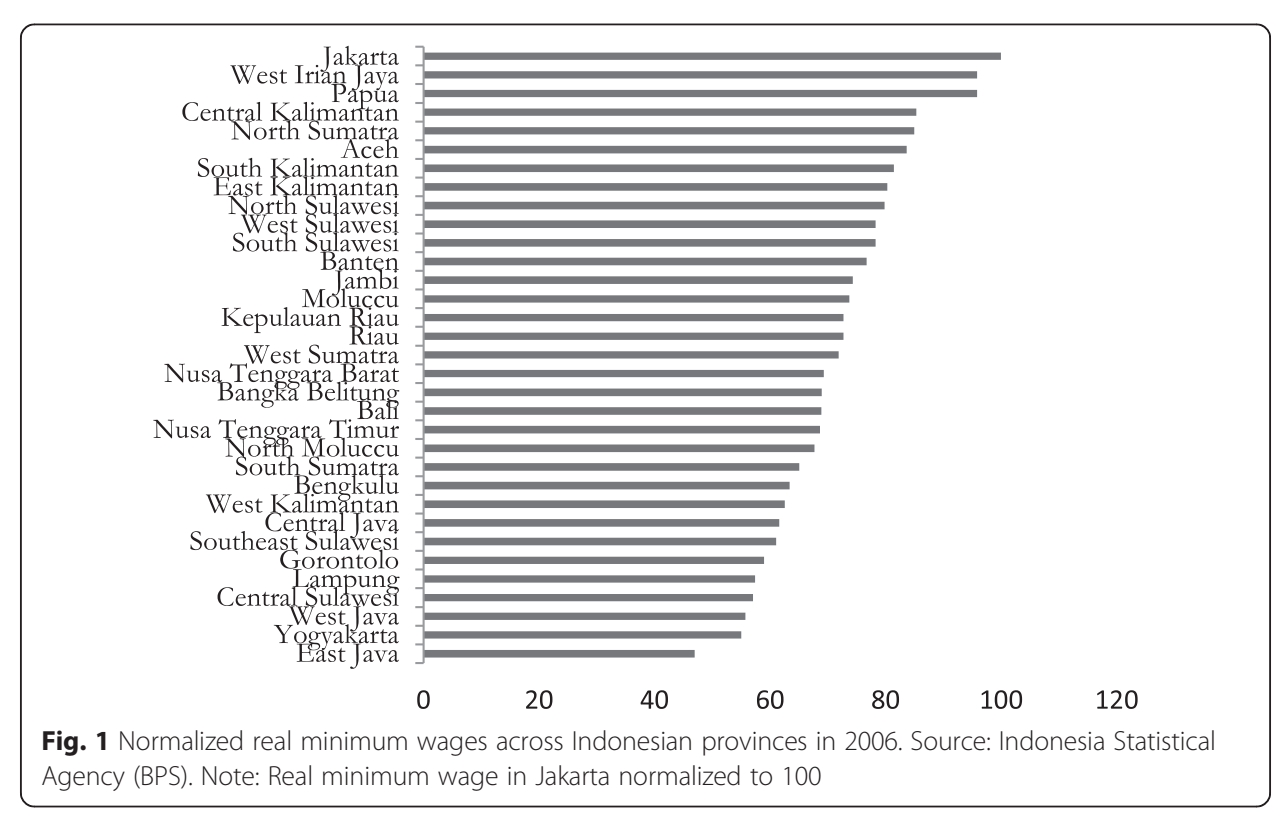


exploitation and labor standards in Indonesia, minimum wage levels began to rise. As reported by Suryahadi et al. (2001), in the first half of the 1990s minimum wages tripled in nominal terms and more than doubled in real terms in a period of five years. During the second half of the 1990s, nominal minimum wages continued to increase but not in real terms due to high levels of inflation. In 1998, the real minimum wage declined as much as $30 \%$ due to the financial crisis, although the nominal wage steadily climbed (see Fig. 2). After the crisis, minimum wages re-emerged as a key element of economic and social policies, with sharp increases in nominal minimum wages. By 2001, the real wage was back at the pre-crisis level, but since then has remained flat.

Compared to other growing economies in East Asia, the monthly minimum wage relative to the countries' GDP per capita is higher in Indonesia than in Thailand or China, ${ }^{7}$ two competing economies. Both Vietnam and the Philippines have higher ratios, while Malaysia still had no statutory minimum wage until very recently.

\section{Data and descriptive analysis}

The main data source used in the analysis is the annual manufacturing census survey of Indonesia (Survei Industri or SI). It was collected and compiled by the Indonesian government's statistical agency (Badan Pusat Statistik or BPS). The survey includes all manufacturing firms that have more than 20 employees, and the multi-modular survey captures detailed questions about the firm and its operation, including output, intermediate inputs, employment, capital, ownership and balance sheet. ${ }^{8}$ The data used in this paper range (inclusively) from 1993 to 2006 . The number of observations varies from about 18,000 firms in 1993 to about 29,000 firms in $2006 .{ }^{9}$ In terms of employment, the survey divides a firm's employment into those of production and of non-production workers, along with the total wage bill for each category, from which it is easy to calculate average wages for production workers and non production workers. For four years 1995, 1996, 1997 and 2006, the survey also has information about the exact educational compositions of its workforce, allowing us to perform analysis on the effects of minimum wage changes on the educational composition of the workforce. Minimum wage data are obtained from BPS. A summary table of variables used in the paper is in the Appendix.

The paper also uses, albeit selectively, data derived from the National SocioEconomic Survey (Susenas). The Susenas is an annual multi-purpose household level

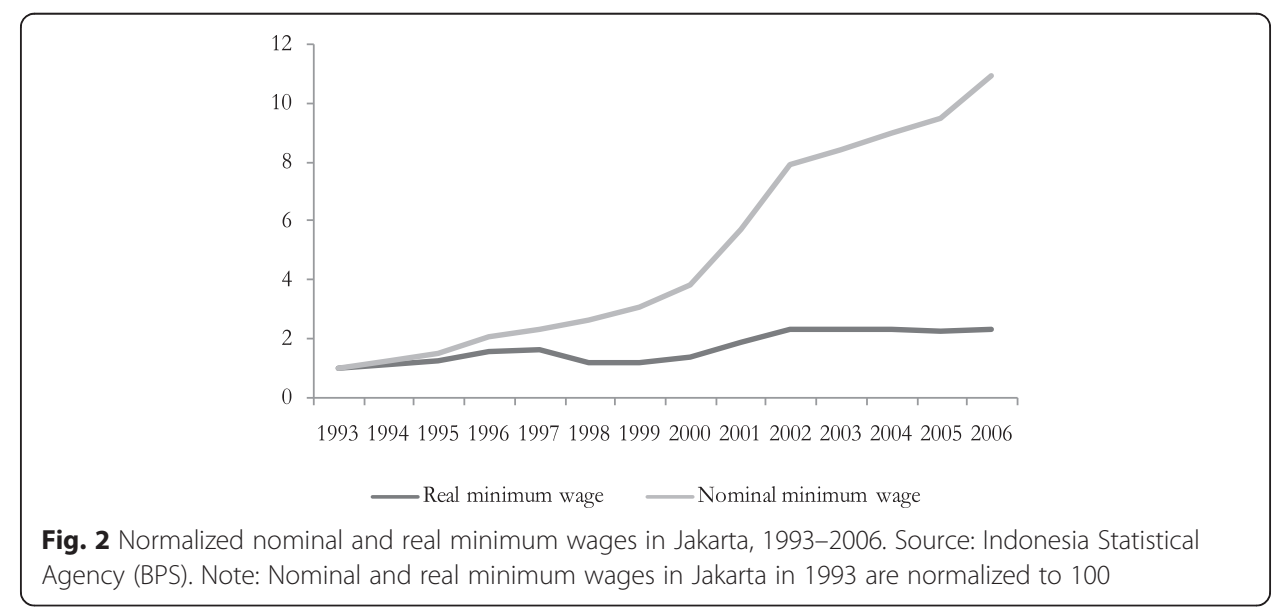


survey that collects individual and household level information, including wages as well as various socio-economic, demographic, and labor characteristics of individuals and households. Comparable waves of this survey are available; however, given that the analysis presented in this paper focuses on firms, the data from Susenas is only used to better understand the results and contextualize the discussion.

The analysis starts by looking at how high minimum wages are relative to workers' wage rates. In order to do so, ideally one would like to have detailed wage distributions within a firm. However, since the data only provides the numbers of production and non-production workers and their respective total wage bills, the calculation focuses on firm average wages. Here minimum wages are compared to the average wage ratio across firms. Figure 3 shows the country average of the minimum wage- firm average wage ratio. It fluctuates from about 0.085 in 1993 to about 0.177 in 2006.

An in-depth look at minimum wage to firm average wage ratio across firms in 2006 reveals that for the majority of firms, the ratio is at the low end (Fig. 4). About $76 \%$ of all firms have a ratio less than 0.1 (i.e. the minimum wage is less than $10 \%$ of the firm's average wage). For less than $1 \%$ of them, the minimum wage is larger than the firm's average wage, indicating that compliance with minimum wage law might be an issue.

This paper focuses on the asymmetric impacts of minimum wages on small firms and large firms. Following Alatas and Cameron (2008), small firms are defined as firms that always have 150 workers or less, and large firms are those that always have more than 150 workers. In the data, there are about 27,000 small firms and about 4500 large firms that appear in the time period evaluated (1993-2006). Small firms and large firms in Indonesia have fundamentally different characteristics. Small firms are overwhelmingly domestic, ${ }^{10}$ have lower productivity levels, lower wages, and are slightly more concentrated in labor-intensive manufacturing ${ }^{11}$ (see Table 1).

Figure 5 reveals that a vast majority of firms are small. In 2006, about $50 \%$ of firms have only 20-40 workers. Out of 29,000 firms, there are only 802 firms with more than 1000 workers and 38 firms with more than 5000 workers.

\section{Empirical strategy}

The analysis focuses on four outcome variables of interest: employment of production workers, employment of non-production workers, changes in workers' educational composition, and real average wages. We exploit the firm panel data to estimate a set of firm fixed effects regressions. In addition, all regression specifications include year

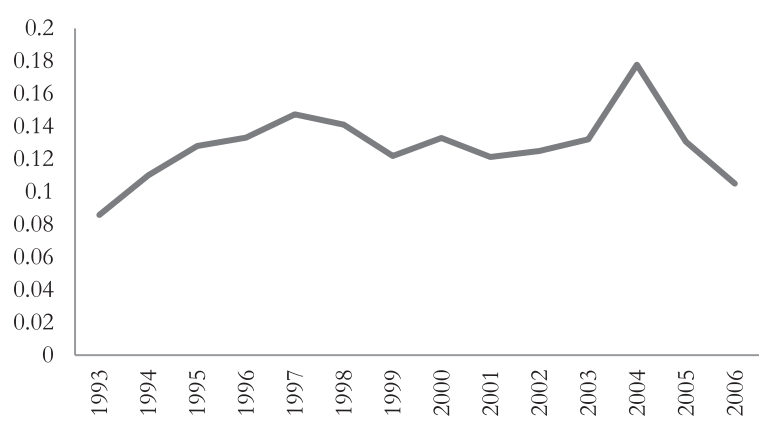

Fig. 3 Minimum wages relative to within firm average wages, 1993-2006. Source: Indonesia Industry Survey (SI) 


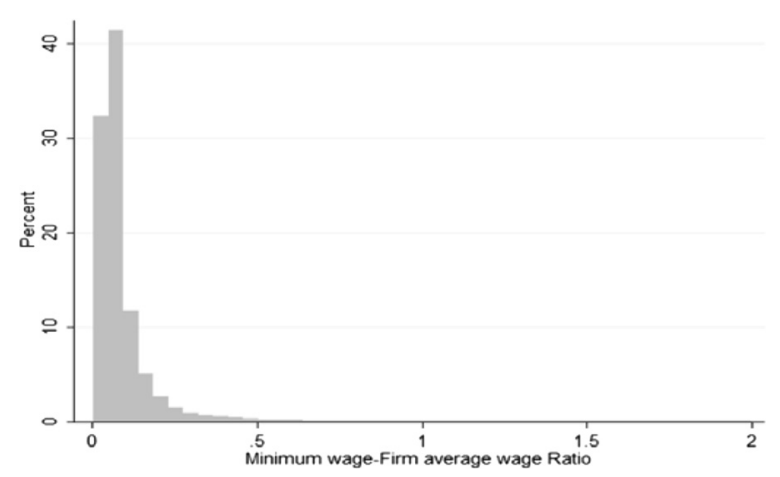

Fig. 4 Firm distribution of minimum wage to average wage ratio, 2006. Source: Indonesia Industry Survey (SI)

effects to capture time varying national macroeconomic factors, such as changes in interest rates, exchange rates, and financial crisis, which influence the economic environment in which all firms operate.

The firm fixed effects regressions take the following form:

$$
\log \left(Y_{i j t}\right)=\alpha_{i}+\alpha_{t}+\beta \log \left(\text { MinWage }_{j t}\right)+\beta_{X}^{\prime} X_{i j t}+\varepsilon_{i j t}
$$

$\log \left(Y_{i j t}\right)$ is the natural $\log$ of the outcome of interest of firm $i$ in province $j$ in year $t$. $\log \left(\right.$ MinWage $\left._{j t}\right)$ is the log of real minimum wage in province $j$ in year $t$. The coefficient $\beta$ measures the elasticity of the outcome of interest with respect to real minimum wages. $X_{i j t}$ is a set of time-varying firm specific control variables. $\alpha_{i}$ is a set of firm fixed effects, while $\alpha_{t}$ is a set of year fixed effects. ${ }^{12}$ The firm fixed effects specification assumes that a province's minimum wage does not respond to changes in employment and wage payment of a particular firm, and the firm varies its employment behavior in response to changes in the minimum wage in the province. This assumption is likely to hold with firm level fixed effects. This is so because of the large heterogeneity among firms, and the near impossibility for one or even a few minimum wage levels to be set in response to every single firm's employment situation.

The endogeneity bias is likely more severe when cross-province data is used to identify the effects of the minimum wage on the outcome of interest. The provincial government is much more likely to take the province-aggregate labor market condition into account when setting the minimum wage level. For example, the provincial government might raise the province's minimum wage when it observes a higher employment level in the province. Thus, estimates based on province data are more likely to suffer from endogeneity bias and biased upward. In the next section, we present evidence that the minimum wage levels are endogenous to labor market conditions of provinces.

Table 1 Firm characteristics in 2006

\begin{tabular}{llllll}
\hline & $\begin{array}{l}\text { Number } \\
\text { of firms }\end{array}$ & $\begin{array}{l}\text { Foreign } \\
\text { firms (\%) }\end{array}$ & $\begin{array}{l}\text { Real value-added per } \\
\text { worker (normalized) }\end{array}$ & $\begin{array}{l}\text { Real wage per worker } \\
\text { (normalized) }\end{array}$ & $\begin{array}{l}\text { Labor-intensive } \\
\text { manufacturing (\%) }\end{array}$ \\
\hline Small firms & 24,079 & $3.71 \%$ & 50.09 & 67.6 & 73 \\
Large firms & 5302 & $23.35 \%$ & 100 & 100 & 64 \\
\hline
\end{tabular}

Source: Indonesia Industry Survey (SI) 


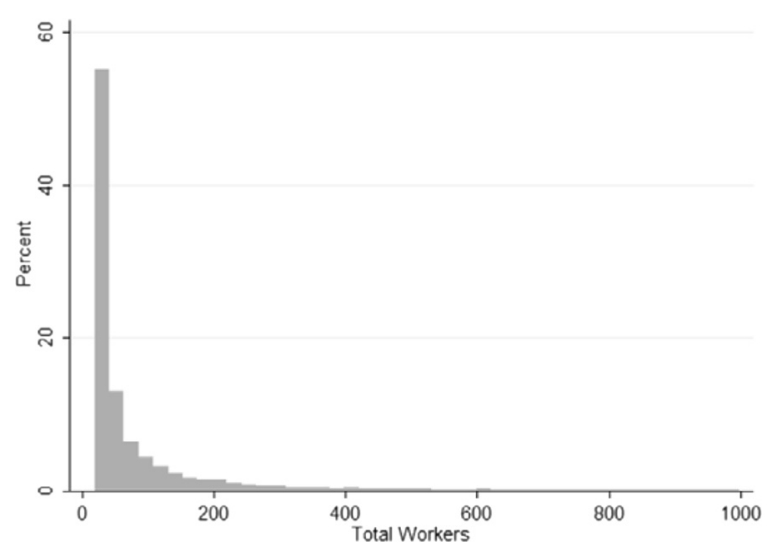

Fig. 5 Distribution of firm size, 2006. Source: Indonesia Industry Survey (SI). Note: Only firms with fewer than 1000 workers are included

\section{Results and discussion}

Four major groups of regressions are shown in this section. The first group focuses on the impact on production worker employment. The second group focuses on the impact on non-production worker employment. The third group focuses on the impact by educational category of workers, and the last group focuses on the impact on real wage firms have to pay their workers. The analysis in the paper and the discussion is based on data from 1993 through 2006.

\subsection{Employment of production workers and non-production workers}

Table 2 reports estimates for all firms based on regression specifications (1) and (2) with the $\log$ of paid production worker employment as the dependent variable (we focus on paid workers only). Furthermore, log of firm's age (Firm age), percentage owned by foreigners (Foreign), percentage of output exported (Export), and percentage owned by local and central government (Government), are included as additional regressors in some specifications to control for some other factors that affect firms' hiring decisions.

Columns (1) and (2) in Table 2 present the effects of minimum wage changes on employment of paid production workers for the whole sample of firms. Column (1) shows that the for every $10 \%$ increase in minimum wage, employment of production workers within a firm is expected to fall by $0.47 \%$ on average. Column (2) shows the elasticity of production employment to minimum wages become -0.34 and statistically insignificant when we include a set of additional regressors. ${ }^{13}$ The slightly drop in the coefficient of the minimum wage when other regressors are added could indicate that the decision of raising the minimum wage may take into account the basic characteristics of firms in provinces. For example, minimum wage may increase at a faster pace in provinces where there is a higher share of export-oriented firms. As we show later in this paper (Section $\mathrm{f}$ ) results for production employment are robust to different time periods within our sample. When the years crisis are dropped from the sample, the coefficient of the minimum wage remain unchanged (negative and statistically significant).

The current estimate is much smaller than previous estimates from other studies. For example, Alatas and Cameron (2008) estimated that employment of production 
Table 2 Employment effects of minimum wages on production workers

\begin{tabular}{|c|c|c|c|c|c|c|}
\hline \multicolumn{7}{|c|}{ Dependent variable: Log (Number of paid production workers) } \\
\hline & \multicolumn{2}{|l|}{ All firms } & \multicolumn{2}{|l|}{ Small firms } & \multicolumn{2}{|c|}{ Large firms } \\
\hline & (1) & (2) & (3) & (4) & (5) & (6) \\
\hline \multirow[t]{2}{*}{ Log (Min. Wage) } & $-0.0469 * * *$ & $-0.0342^{* *}$ & $-0.0251^{* *}$ & $-0.0265^{*}$ & -0.0270 & 0.0166 \\
\hline & $(0.0136)$ & $(0.0161)$ & $(0.0120)$ & $(0.0145)$ & $(0.0265)$ & $(0.0312)$ \\
\hline \multirow[t]{2}{*}{ Log (Firm Age) } & & $0.1881^{* * *}$ & & $0.0982^{* * *}$ & & $0.2293^{* * *}$ \\
\hline & & $(0.0065)$ & & $(0.0056)$ & & $(0.0135)$ \\
\hline \multirow[t]{2}{*}{ Foreign Share } & & $0.0019^{* * *}$ & & $0.0007^{* * *}$ & & $0.0013^{* * *}$ \\
\hline & & $(0.0002)$ & & $(0.0002)$ & & $(0.0002)$ \\
\hline \multirow[t]{2}{*}{ Export Share } & & $0.0007^{* * *}$ & & $0.0005^{* * *}$ & & $0.0003^{* * *}$ \\
\hline & & $(0.0001)$ & & $(0.0001)$ & & $(0.0001)$ \\
\hline \multirow[t]{2}{*}{ Govt. Share } & & 0.0001 & & -0.0000 & & 0.0001 \\
\hline & & $(0.0002)$ & & $(0.0001)$ & & $(0.0003)$ \\
\hline Fixed Effects & Firm & Firm & Firm & Firm & Firm & Firm \\
\hline Year Effects & Yes & Yes & Yes & Yes & Yes & Yes \\
\hline Observations & 290,118 & 206,375 & 221,300 & 157,761 & 66,677 & 47,117 \\
\hline Number of Firms & 40,169 & 38,563 & 35,188 & 33,534 & 9285 & 8893 \\
\hline R-squared & 0.916 & 0.919 & 0.802 & 0.809 & 0.846 & 0.851 \\
\hline
\end{tabular}

Notes: The sample includes only firms with non-zero production and non-production workers, firms that continuously observed from year to year, and firms observed more than once during the sample period (1993-2006). Columns (2) (4) and (6) have fewer observations than other columns because the additional regressors have missing values in 2001, 2002, 2003, and 2005. Robust standard errors clustered by firm are reported in parentheses. ${ }^{* *} p<0.01,{ }^{* *} p<0.05,{ }^{*} p<0.1$

workers would fall by 5\% and Harrison and Scorse (2010) estimated that employment of production workers would fall by $1.2 \%$, for every $10 \%$ increase in minimum wage. This can partly be explained by the fact that all three studies use different samples and evaluate the impact on different time periods.

Columns (3) and (4) in Table 2 examine the effects of minimum wage changes on employment of paid production workers among small firms (i.e., firms with 150 or fewer workers during the sample period). The results suggest that minimum wage changes have a negative effect on employment of production workers of small firms, but the coefficient is statistically insignificant in both specifications. Columns (5) and (6) report estimates for firms that always employed more than 150 workers during the sample period. The effect of minimum wages on employment of production workers is statistically insignificant in both specifications. The coefficient estimates are smaller in magnitudes while standard errors are similar compared to those for small firms, suggesting that employment of production workers in large firms are not responsive to minimum wage changes.

In the second group of regressions, the focus is on employment of non-production workers. As mentioned above, past studies tend not to focus on non-production workers, as conventional wisdom associate non-production workers with skilled, highly-paid workers. Although the total number of non-production workers is about one-fifth of production workers' in the data and the number is stable for the entire sample period, household data from Susenas show that the estimated share of nonproduction workers (ages 15-65) in the manufacturing sector in 2006 is non-trivial, about $47 \%$. Presumably, many of them work in small firms with less than 20 workers, which are not covered in the survey. Table 3 summarizes the results using the log of 
Table 3 Employment effects of min. wages on non- prod. workers

\begin{tabular}{|c|c|c|c|c|c|c|}
\hline \multicolumn{7}{|c|}{ Dependent variable: Log (Number of paid non-production workers) } \\
\hline & \multicolumn{2}{|l|}{ All firms } & \multicolumn{2}{|l|}{ Small firms } & \multicolumn{2}{|c|}{ Large firms } \\
\hline & (1) & (2) & (3) & (4) & (5) & (6) \\
\hline \multirow[t]{2}{*}{ Log (Min. Wage) } & $-0.0615^{* * *}$ & $-0.0554^{* *}$ & $-0.0649 * * *$ & $-0.0779^{* * *}$ & 0.0105 & 0.0635 \\
\hline & $(0.0206)$ & $(0.0250)$ & $(0.0213)$ & $(0.0263)$ & $(0.0409)$ & $(0.0494)$ \\
\hline \multirow[t]{2}{*}{ Log (Firm Age) } & & $0.1942^{* * *}$ & & $0.0954^{* * *}$ & & $0.2516^{* * *}$ \\
\hline & & $(0.0098)$ & & $(0.0100)$ & & $(0.0210)$ \\
\hline \multirow[t]{2}{*}{ Foreign Share } & & $0.0012^{* * *}$ & & $0.0017^{* * *}$ & & 0.0000 \\
\hline & & $(0.0003)$ & & $(0.0004)$ & & $(0.0004)$ \\
\hline \multirow[t]{2}{*}{ Export Share } & & $0.0007^{* * *}$ & & $0.0006^{* * *}$ & & $0.0003^{* *}$ \\
\hline & & $(0.0001)$ & & $(0.0001)$ & & $(0.0001)$ \\
\hline \multirow[t]{2}{*}{ Govt. Share } & & $0.0007^{* *}$ & & $0.0007^{* * *}$ & & 0.0003 \\
\hline & & $(0.0003)$ & & $(0.0002)$ & & $(0.0004)$ \\
\hline Fixed Effects & Firm & Firm & Firm & Firm & Firm & Firm \\
\hline Year Effects & Yes & Yes & Yes & Yes & Yes & Yes \\
\hline Observations & 245,963 & 168,741 & 179,746 & 121,950 & 64,414 & 45,568 \\
\hline Number of firms & 36,893 & 34,504 & 31,821 & 29,389 & 9159 & 8762 \\
\hline R-squared & 0.873 & 0.876 & 0.814 & 0.821 & 0.761 & 0.773 \\
\hline
\end{tabular}

Notes: The sample includes only firms with non-zero production and non-production workers, firms that continuously observed from year to year, and firms observed more than once during the sample period (1993-2006). Columns (2) (4) and (6) have fewer observations than other columns because the additional regressors have missing values in 2001, 2002, 2003, and 2005. Robust standard errors clustered by firm are reported in parentheses. ${ }^{* *} p<0.01,{ }^{* *} p<0.05,{ }^{*} p<0.1$

paid non-production worker employment as the dependent variable for all firms, small firms, and large firms, respectively.

Table 3 indicates that the effect of minimum wages on employment is more pronounced and significant for non-production workers than for production workers. Column (1) shows that a $10 \%$ increase in real minimum wages will lead to a $0.61 \%$ decline in employment of non-production workers in all firms, on average. Column (2) shows that including additional regressors does not alter the estimated elasticity of employment of non-production workers to minimum wage in all firms. The negative impact of minimum wages on employment of non-production workers is more significant than that on production workers.

Columns (3) and (4) in Table 3 show that the negative effect of minimum wages on employment of non-production workers is pronounced among small firms. The estimates suggest that for every $10 \%$ increase in the real minimum wage, employment of non-production workers among small firms is expected to fall between 0.64 percent and 0.77 percent. On the other hand, Columns (5) and (6) shows that minimum wage changes have no negative effect on the employment of non-production workers in large firms. The estimates are positive and insignificant in both specifications. However, under alternative definitions of large firms, changes in the minimum wage may have a statistically significant and still positive effect on the employment of non-production workers (see in section $f$ the robustness analysis).

The negative effect of minimum wage changes on employment of non-production workers is several times larger than that of production workers. This is initially surprising because non-production workers are generally thought as more educated than production workers, and therefore should be less vulnerable to changes in minimum wages. While non-production workers are indeed generally more educated than production workers, a 
large fraction of them still has low levels of education. As we can see in Fig. 6, close to 85 percent of non-production workers in manufacturing have less than high school education, while this figure rises to 98 percent among production workers. The heterogeneity of nonproduction jobs, and that low end non-production workers receive low wages might explain the negative impact of minimum wages on non-production workers. We also observe a high heterogeneity in the gender composition of non-production employment. While there is an equal distribution of production employment among women and men, non-production employment is mostly performed by male, almost $70 \%$ of workers are male and $30 \%$ are women.

Household data also confirms these points. There are at least three distinct occupation categories among non-production workers in manufacturing: management and administrative staff, sales people, and workers performing menial tasks. As expected, workers in the management and administrative category have higher levels of education, where at least $80 \%$ of them have completed high school. On the other hand, about 40 percent of sales people and 70 percent of workers performing basic tasks have not completed high school (Fig. 7).

Household data also show that over half of all non-production workers with less than primary school education earn at or below the national minimum wage (Fig. 8), suggesting that they account for the majority of job losses. ${ }^{14}$ These workers earn low wages, are more likely low skilled (with primary education or less) and tend to perform non-essential tasks in the factories, thus making them extremely vulnerable to wage hikes. In part (c) the discussion delves deeper into different education categories of production and non-production workers.

\subsection{Asymmetric impacts of minimum wages on large firms and small firms}

It is critical to understand why minimum wages hurt employment of non-production workers in small firms but not in large firms. Perhaps small firms tend to pay their workers lower wages on average, and thus must cut employment aggressively in response to a higher minimum wage. In contrast, large firms are less responsive to minimum wage changes, as they may not only have monopsony power in the labor market, but also pay higher wages on average due to higher labor productivity and the extensive use of capital. Data confirm that the average wages of workers in small firms are

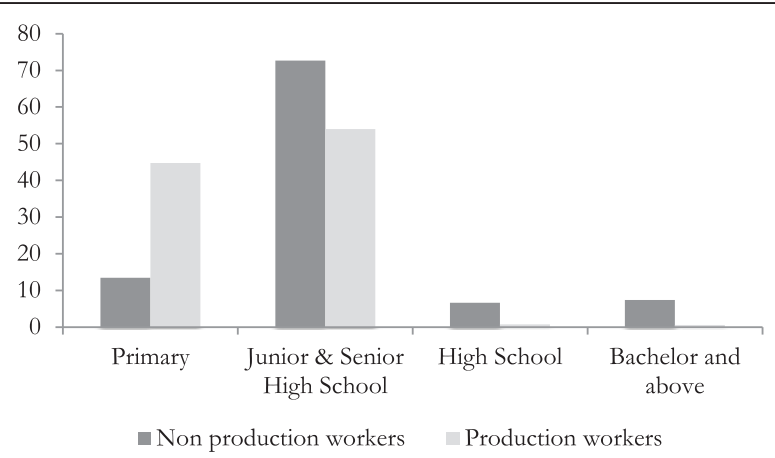

Fig. 6 Education composition of production and non-production workers, 2006. Source: Indonesia Industry Survey (SI) 


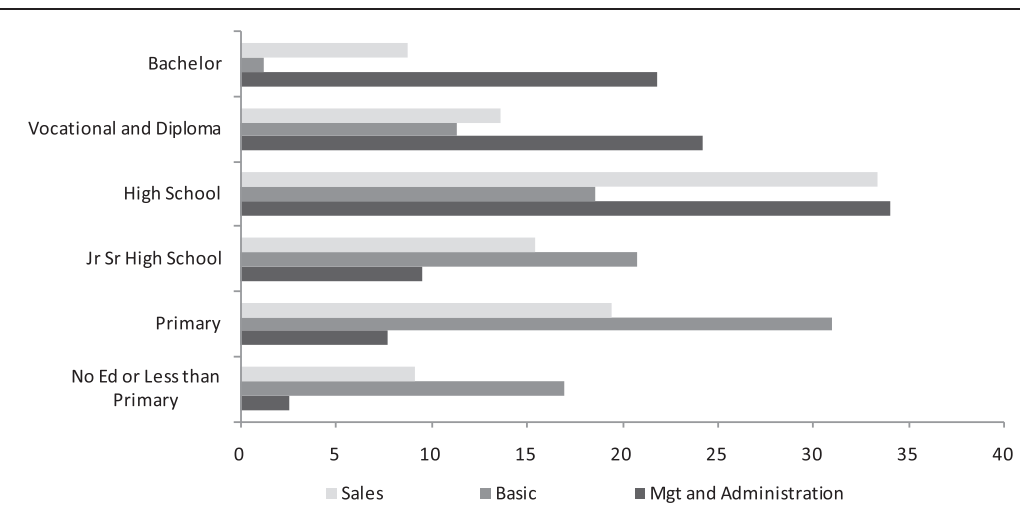

Source: Susenas 2006

Fig. 7 Education levels of distinct types of non-production workers in the manufacturing sector, 2006. Source: Susenas 2006

significantly lower than average wages of workers in large firms (see Table 1 and Fig. 9). The difference is much more pronounced among non-production workers: average non-production wages in large firms are at least twice as high as wages in small firms.

It is then important to understand why large firms pay workers higher salaries. One reason could be related to different skill levels (proxied by their educational attainment). Among non-production workers, the percentage of workers with at least bachelor education is twice as high in large firms as in small firms (16.1 percent compared to 8.7 percent, in 2006) (Fig. 10). This probably accounts for a part of the wage discrepancy between non-production wages in large firms and small firms. On the other hand, the differences between production workers with at least a high school diploma and those without are similar between large firms and small firms.

Another potential reason is that large firms might have a higher degree of mechanization, which explains why the value added per worker in large firms is higher and workers in large firms are better paid (see Table 1). The data seem to confirm this conjecture: the estimated value of machine capital per worker is much larger in large

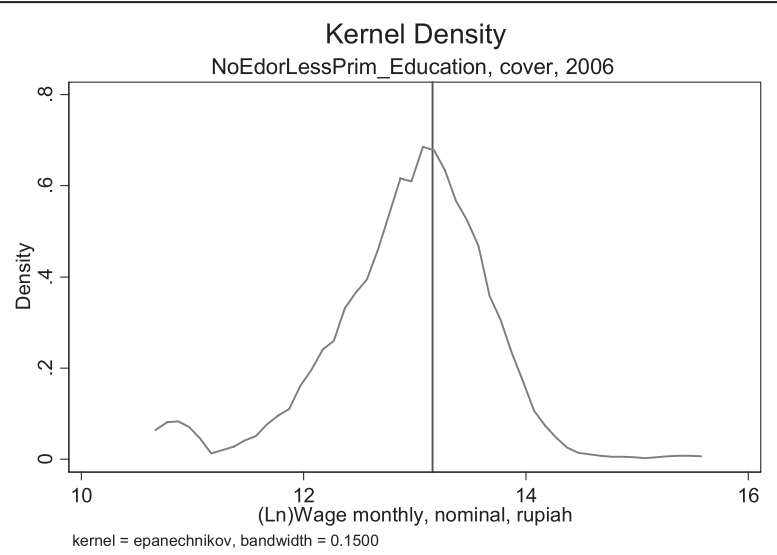

Fig. 8 Wages for non-production "Basic" workers with low education levels in the manufacturing sector, 2006. Source: Susenas, 2006 


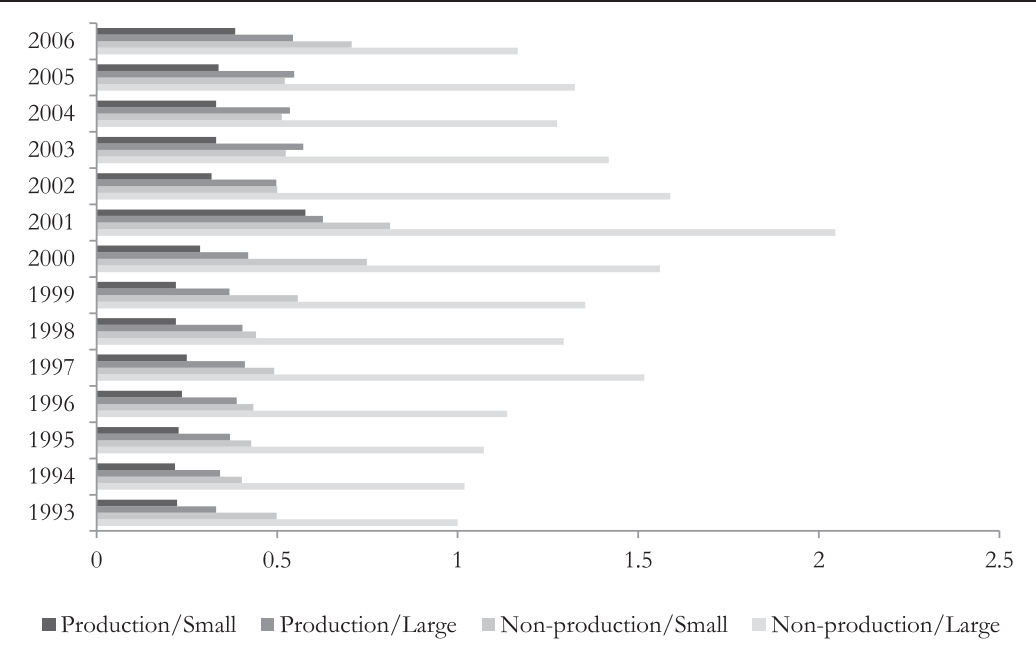

Fig. 9 Normalized firm-average real wage of production workers and non-production workers in small firms and large firms. Source: Indonesia Industry Survey (SI). Note: Firm average real wage of non-production workers in large firms in 1993 is normalized to 1

firms. For the years where the estimated values of machine capital are available, the estimate for firms in Jakarta area shows that the estimated value of machine capital per worker of large firms is 1.4 to 16 times larger than that of small firms.

Figure 9 also reveals that on average, non-production workers receive higher wages than production workers. The fact that non-production workers are more vulnerable to minimum wage rises could indicate several things. First, there may be a large dispersion in wages (or wage inequality) among non-production workers within a firm; unfortunately, the data does not allow us to confirm this point. Second, and related to the first point, the large dispersion of wages within the group likely hide the fact that a subset of nonproduction workers earns very little (for instance, janitors and cleaners), while a subset earn very high wages (for instance, managers).

\subsection{Educational compositions of production and non-production workers}

The third group of regressions helps look at employment changes by education in response to minimum wage changes. There are several questions of interest here. First, which groups of workers are most hurt by minimum wage changes? Second, do firms

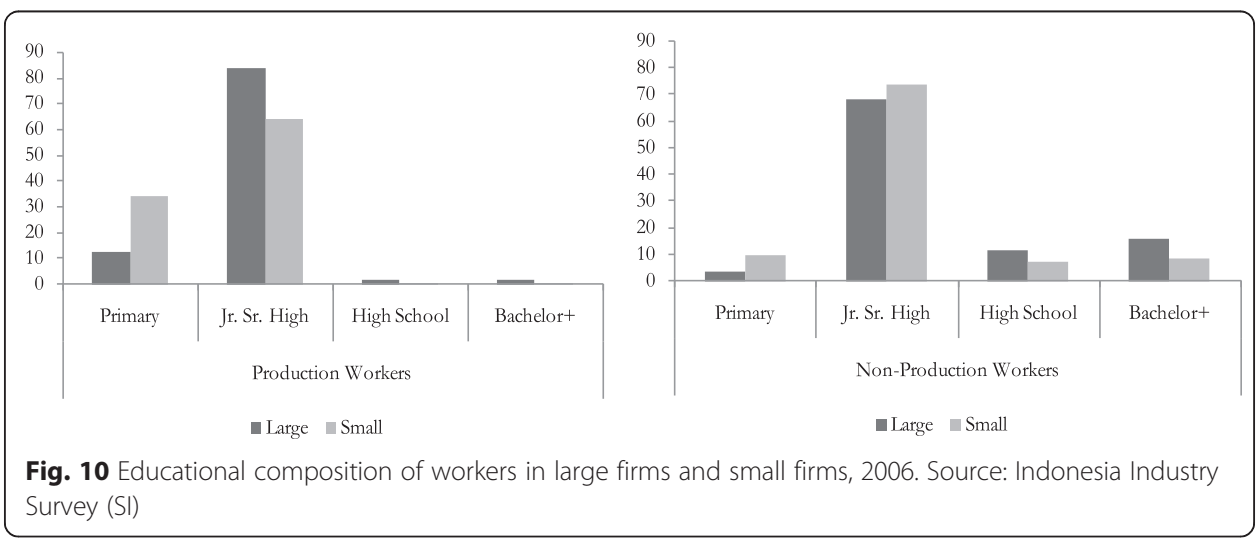




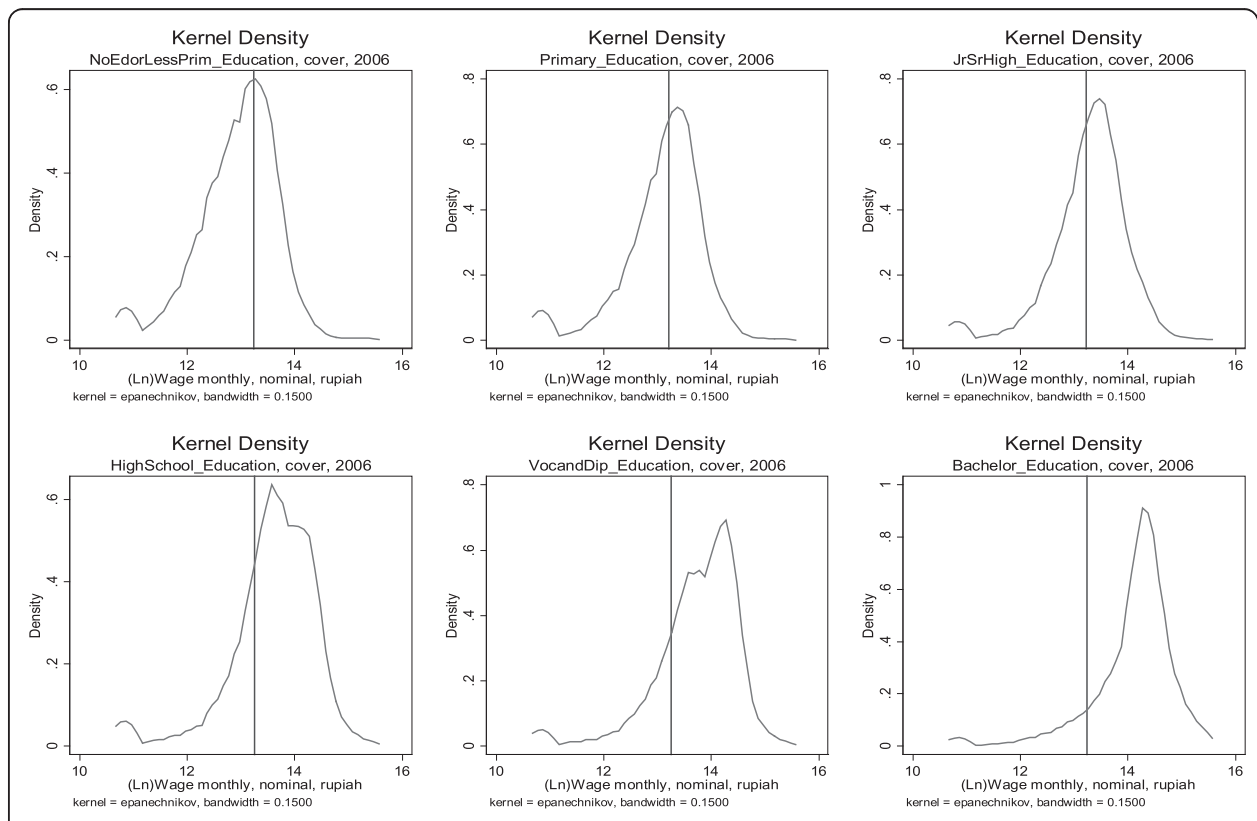

Fig. 11 Wage density curves for non-production workers by education level across all economic sectors, 2006. Source: Susenas, 2006

substitute low-skilled workers for higher skilled workers in response to minimum wage increases? Since detailed skill portfolios of workers are not available, we use education as a proxy for skill to examine these questions.

The focus of this part of the analysis is on small firms because they are where the majority of the workforce is, and where there are interesting dynamics. Employment of production and non-production workers is analyzed separately. For each group of workers, the analysis measures percentage changes of the following education categories: at most primary education (primary); junior high and incomplete senior high (juniorseniorhigh); high school diploma (highschool); university and above (bachelor). ${ }^{15}$ Note that data are only available for 1995, 1996, 1997, and 2006.

Table 4 reports the estimates for employment of production workers by educational category. Results shows that production workers with lower levels of education (senior high and below) are negatively affected by an increase in the minimum wage. In particular, the effect on production workers with junior and senior high school education is significant. Within a firm, a 10 percent increase in the minimum wage is expected to decrease the number of workers with junior high or senior high school education by 2 percent on average. On the other hand, the effects on production workers with high school degree and above are positive and insignificant.

Table 5 summarizes the results from the analysis of employment of non-production workers by educational category. The negative effects of minimum wage changes are significant for non-production workers without high school diploma but insignificant for those with at least a high school diploma. A 10\% increase in the minimum wage causes employment of non-production workers with no more than primary education to fall by 2.9 percent. This effect is several times larger than the average decline. Similarly to production workers' employment, minimum wage increases hurt non-production workers without high school education. Moreover, there is no evidence of substitution from less educated workers 
Table 4 Employment effects of minimum wages on production workers in small firms by educational category

\begin{tabular}{|c|c|c|c|c|}
\hline & \multicolumn{4}{|c|}{ Dependent variable: Log (Employment of production workers) } \\
\hline & Primary & Jr. Sr. High & High School & Bachelor \\
\hline \multirow[t]{2}{*}{ Log (Min. Wage) } & -0.0855 & $-0.1957^{* * *}$ & 0.0233 & 0.0891 \\
\hline & $(0.0723)$ & $(0.0552)$ & $(0.2155)$ & $(0.1978)$ \\
\hline \multirow[t]{2}{*}{ Log (Firm Age) } & $0.0940^{* * *}$ & $0.0691^{* * *}$ & $-0.2686^{* * *}$ & $-0.2768^{* * *}$ \\
\hline & $(0.0272)$ & $(0.0202)$ & $(0.0688)$ & $(0.0779)$ \\
\hline \multirow[t]{2}{*}{ Foreign Share } & -0.0008 & 0.0002 & $0.0032^{*}$ & 0.0012 \\
\hline & $(0.0010)$ & $(0.0006)$ & $(0.0017)$ & $(0.0015)$ \\
\hline \multirow[t]{2}{*}{ Export Share } & 0.0003 & $0.0007^{* * *}$ & -0.0001 & 0.0009 \\
\hline & $(0.0003)$ & $(0.0002)$ & $(0.0008)$ & $(0.0007)$ \\
\hline \multirow[t]{2}{*}{ Govt. Share } & 0.0006 & $0.0013^{* * *}$ & 0.0001 & -0.0004 \\
\hline & $(0.0006)$ & $(0.0005)$ & $(0.0014)$ & $(0.0013)$ \\
\hline Firm Fixed Effects & Yes & Yes & Yes & Yes \\
\hline Year Effects & Yes & Yes & Yes & Yes \\
\hline Number of Firms & 16,360 & 19,036 & 3592 & 3087 \\
\hline Observations & 35,634 & 40,865 & 5159 & 4502 \\
\hline R-squared & 0.8622 & 0.8645 & 0.8953 & 0.9104 \\
\hline
\end{tabular}

Notes: The sample includes only small firms with non-zero production and non-production workers, small firms that continuously observed from year to year, and small firms observed more than once during the sample period. Small firms are firms which always have 150 or fewer workers. Data of workers' educational composition are available in 1995, 1996, 1997, and 2006. Robust standard errors clustered by firm are reported in parentheses. ${ }^{* * *} p<0.01,{ }^{* *} p<0.05,{ }^{*} p<0.1$

to more educated workers; instead, only less educated workers are let go. As mentioned above, non-production jobs, particularly those performed by low-educated workers, are not management or research related, but mostly menial jobs.

Appendix presents the impacts of minimum wage on large firms. We do not observe any significant effects of the minimum wage on the employment of production workers (Appendix). This is probably for large firms, with more capital, the marginal productivity of each production worker is higher than that in small firms. Therefore, production workers in large firms are less affected by minimum wage changes. For non-production workers in large firms, the impacts of minimum wage changes are not as trivial. They reduce employment of non-production workers with junior- high and high school education and increase the employment of workers with less than primary education (Appendix). This result could indicate that large firms tend to substitute more educated workers (those more likely to be formal and earning the minimum wage) for less educated workers (who are more likely to be informal and paid under the minimum wage), while compliance may be going down and overall employment remained unchanged.

Figure 12 shows the wage distribution of non-production workers by education level for all sectors of the economy and illustrates the tendency of less educated nonproduction workers to earn low wages and be more vulnerable to minimum wage changes. The first three diagrams in the first row show the wage distributions of nonproduction workers with no or less than primary education, with primary education and with junior and senior high school education. Almost half of them receive lower wages than the (national average) minimum wage-shown as the vertical lines in the diagrams. 
Table 5 Employment effects of minimum wages on non-production workers in small firms by educational category

\begin{tabular}{|c|c|c|c|c|}
\hline & \multicolumn{4}{|c|}{ Dependent variable: Log (Employment of non-production workers) } \\
\hline & Primary & Jr. Sr. High & High School & Bachelor \\
\hline \multirow[t]{2}{*}{ Log (Min. Wage) } & $-0.2915^{*}$ & $-0.1553^{* * *}$ & -0.0751 & -0.0490 \\
\hline & $(0.1660)$ & $(0.0497)$ & $(0.1114)$ & (0.1026) \\
\hline \multirow[t]{2}{*}{ Log (Firm Age) } & 0.0483 & $0.1104^{* * *}$ & $-0.1204^{* * *}$ & $-0.1803^{* * *}$ \\
\hline & $(0.0531)$ & $(0.0191)$ & $(0.0400)$ & $(0.0349)$ \\
\hline \multirow[t]{2}{*}{ Foreign Share } & $-0.0027^{*}$ & $0.0021^{* * *}$ & 0.0008 & -0.0006 \\
\hline & $(0.0016)$ & $(0.0006)$ & $(0.0011)$ & $(0.0009)$ \\
\hline \multirow[t]{2}{*}{ Export Share } & -0.0008 & 0.0001 & 0.0006 & 0.00003 \\
\hline & $(0.0005)$ & $(0.0003)$ & $(0.0005)$ & $(0.0004)$ \\
\hline \multirow[t]{2}{*}{ Govt. Share } & 0.0010 & 0.00004 & -0.0016 & $-0.0017^{*}$ \\
\hline & $(0.0011)$ & $(0.0005)$ & $(0.0010)$ & $(0.0009)$ \\
\hline Firm Fixed Effects & Yes & Yes & Yes & Yes \\
\hline Year Effects & Yes & Yes & Yes & Yes \\
\hline Number of Firms & 7707 & 19,126 & 7234 & 7208 \\
\hline Observations & 13,571 & 41,823 & 11,982 & 12,523 \\
\hline R-squared & 0.8888 & 0.8596 & 0.8431 & 0.8239 \\
\hline
\end{tabular}

Notes: The sample includes only small firms with non-zero production and non-production workers, small firms that continuously observed from year to year, and small firms observed more than once during the sample period. Small firms are firms which always have 150 or fewer workers. Data of workers' educational composition are available in 1995, 1996, 1997, and 2006. Robust standard errors clustered by firm are reported in parentheses. ${ }^{* *} p<0.01,{ }^{* *} p<0.05,{ }^{*} p<0.1$

\subsection{Employment of male and female workers}

The fourth group of regressions focuses on the minimum wage effect on employment by gender. The question of interest is whether a rise in minimum wages attracts broader female participation to the formal labor force in the manufacturing sector or leads to greater job losses among women workers. As shown before, of all working-age women only 52 percent of them were actively working or looking for work in 2006; this is low compared to male participation in the country (86 percent). Time-use surveys from around the world reveal that women are largely responsible for housework and raising children (Miranda, 2011). As a result of the double burden some studies conclude that women's reservation wage in many cases is higher than what the market is willing to pay them, keeping them out of the labor force. Recent evidence on the other hand shows that many women, especially among lower economic quintiles, lower their reservation wage and enter the labor force to finance basic expenditures of having children (Priebe, 2010). Thus, one can argue that a rise in the minimum wages could potentially attract women to the labor market. On the other hand, women are usually less educated and less well-paid than men in developing countries. Women may also suffer from gender discrimination in the labor market, as women earn between 70 and 80 percent the wages of men for similar work in many countries (Hausmann et al. 2010). ${ }^{16}$ Women workers, especially less educated ones, may be the first laid off when firms are compelled to pay higher minimum wages.

Table 6 shows the detailed analysis. Four items are measured here: employment of male production workers, of female production workers, of male non-production workers, and of female non-production workers. The dependent variables are log of employment of the four categories; and as in previous sections the same control variables and firms fixed effects are included. 


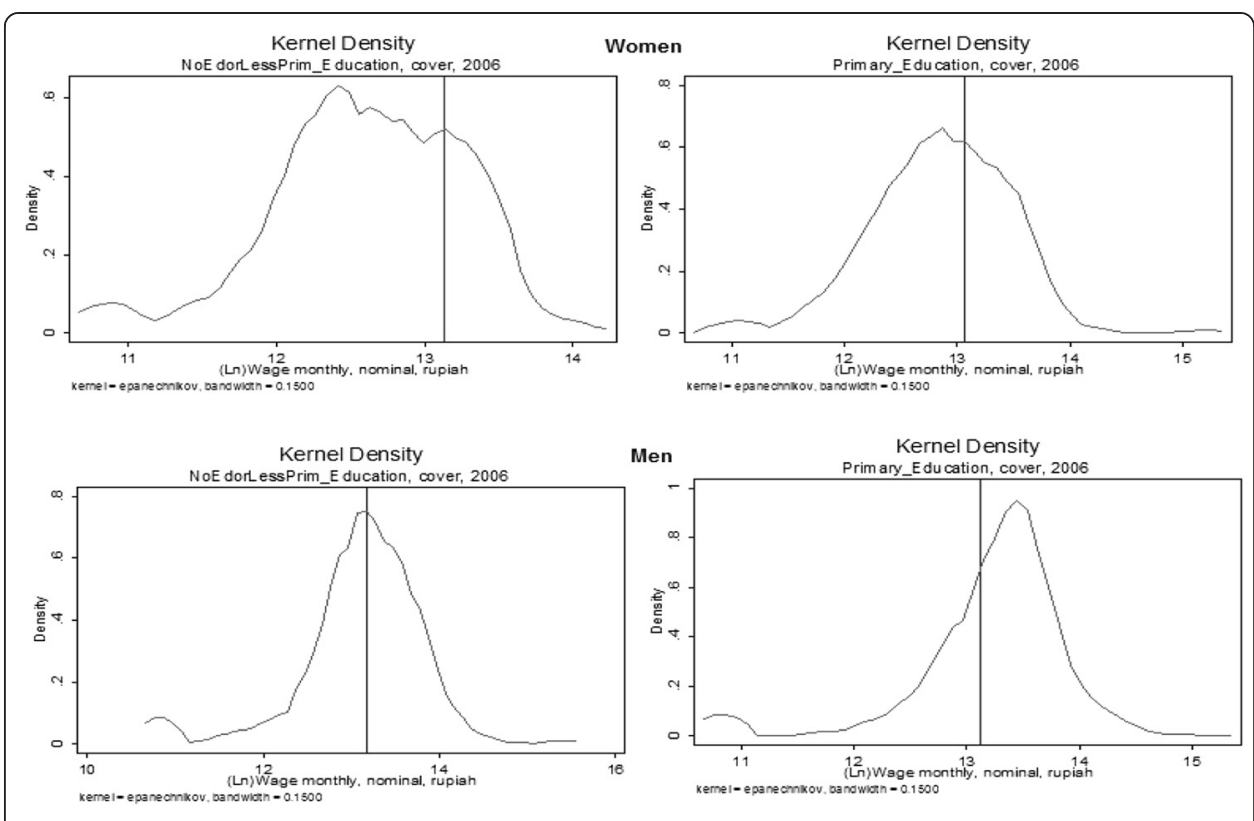

Fig. 12 Wage distribution of low skilled non-production workers in 2006, by gender. Source: Susenas, 2006

The results show that a rise in minimum wages disproportionately hurts female workers, especially those performing non-production jobs. They bear most of the burden of job losses. The negative impact on female non-production workers is large, statistically significant and robust. A 10 percent increase in minimum wage leads to 0.6 percent - 0.7 percent decline in female non-production employment in small firms. The impact of minimum wages on male workers is negative, with a smaller coefficient and not statistically significant.

The firm survey does not have detailed information on education of non-production workers by gender and it is not possible to disentangle the gender effects by education. We use household survey in 2006 to examine the wage distribution of non-production workers with primary education or less by gender (Fig. 12) to provide further analysis. Note that the vertical line indicates the value of a hypothetical national minimum wage in 2006. The figures show that the wage densities for women are concentrated to the left of the line, but not for men with similarly low levels of education. Thus, the results are consistent with the view that non-production female workers are more likely laid off when the minimum wage is raised because they are less well paid than men.

\subsection{Wage rates of production workers and non-production workers}

This section examines if changes in minimum wages have impacts on firms' average wage rates. The relevant question is whether firms adjust their wages in response to minimum wages. One cannot fully rule out the issue of reverse causality because it is plausible that the government sets minimum wages to take into account the aggregate wage growth. In other words, higher minimum wages are because the aggregate wage is higher. Therefore, the estimates for the impact of minimum wages on the actual wage rates can be biased upward. But as explained before, it is very difficult to expect that all firms are coordinating the way in which they set their wages and one or a few 
Table 6 Employment effects of minimum wages on male and female workers in small firms

\begin{tabular}{|c|c|c|c|c|c|c|c|c|}
\hline & \multicolumn{8}{|c|}{ Dependent variable: } \\
\hline & \multicolumn{4}{|c|}{$\begin{array}{l}\text { Log of Employment of Production } \\
\text { Workers }\end{array}$} & \multicolumn{4}{|c|}{$\begin{array}{l}\text { Log of Employment of Non-Production } \\
\text { Workers }\end{array}$} \\
\hline & Male & & Female & & Male & & Female & \\
\hline \multirow[t]{2}{*}{ Log (Min. Wage) } & -0.0258 & -0.0208 & $-0.058^{* *}$ & -0.0430 & -0.0365 & -0.0290 & $-0.061^{* * *}$ & $-0.0692^{* *}$ \\
\hline & $(0.0174)$ & $(0.0210)$ & $(0.0245)$ & (0.0309) & $(0.0236)$ & $(0.0289)$ & $(0.0227)$ & $(0.0287)$ \\
\hline \multirow[t]{2}{*}{ Log (Firm Age) } & & $0.1202^{* * *}$ & & $0.0964^{* * *}$ & & $0.1003^{* * *}$ & & $0.0802^{* * *}$ \\
\hline & & $(0.0081)$ & & $(0.0122)$ & & $(0.0110)$ & & $(0.0108)$ \\
\hline \multirow[t]{2}{*}{ Foreign Share } & & $0.0007^{* *}$ & & 0.0001 & & $0.0019^{* * *}$ & & $0.0013^{* * *}$ \\
\hline & & $(0.0003)$ & & $(0.0006)$ & & $(0.0005)$ & & $(0.0004)$ \\
\hline \multirow[t]{2}{*}{ Export Share } & & $0.0003^{* * *}$ & & $0.0007^{* * *}$ & & $0.0004^{* *}$ & & $0.0005^{* * *}$ \\
\hline & & $(0.0001)$ & & $(0.0001)$ & & $(0.0001)$ & & $(0.0001)$ \\
\hline \multirow[t]{2}{*}{ Govt. Share } & & 0.0001 & & $-0.0005^{* *}$ & & $0.0009^{* * *}$ & & -0.0000 \\
\hline & & $(0.0002)$ & & $(0.0003)$ & & $(0.0003)$ & & $(0.0002)$ \\
\hline Firm Fixed Effects & Yes & Yes & Yes & Yes & Yes & Yes & Yes & Yes \\
\hline Year Effects & Yes & Yes & Yes & Yes & Yes & Yes & Yes & Yes \\
\hline Observations & 167,873 & 113,780 & 126,026 & 83,780 & 159,346 & 106,834 & 129,736 & 85,473 \\
\hline Number of Firms & 27,500 & 25,894 & 23,351 & 21,616 & 27,122 & 25,282 & 23,897 & 21,890 \\
\hline R-squared & 0.8450 & 0.8498 & 0.8522 & 0.8591 & 0.8086 & 0.8104 & 0.7678 & 0.7708 \\
\hline
\end{tabular}

Notes: The sample includes only small firms with non-zero production and non-production workers, small firms that continuously observed from year to year, and small firms observed more than once during the sample period. Small firms are firms which always have 150 or fewer workers. Both paid and unpaid workers are included as data since 2001 do not permit separation of paid and unpaid workers by gender. The additional regressors have missing values in 2001, 2002, 2003, and 2005. Robust standard errors clustered by firm are reported in parentheses. ${ }^{* *} p<0.01,{ }^{* *} p<0.05,{ }^{*} p<0.1$

minimum wage levels cannot correspond to all firms' wage setting. Therefore, with firm fixed effects, it is likely that reverse causality is mitigated. The dependent variable of interest is log of real firm-average wages (in cash and in kind) per worker. The results for production workers are presented in Table 7, and the results for non-production workers are in Table 8. The list of other control variables is similar.

Results reveal that in general, the association between minimum wages and firms' actual wages, for both production workers and non-production workers, is robust and significant. For production workers, a 10 percent increase in real minimum wages is associated with a 1.8 percent increase in wages in small firms, but only 0.8 percent increase in wages in large firms. For non-production workers, a 10 percent increase in real minimum wages is associated with a 1.65 percent increase in wages in small firms, but only 1.2 percent in larger firms. The association between minimum wages and actual wages is significant, of large magnitude in small firms, but less so in larger firms. This suggests that wages in small firms are more sensitive to changes in minimum wages, which is consistent with the fact that on average, wages in small firms are significantly lower. In other words, small firms are more likely to raise their wages in response to an increase in minimum wages because their wages are more binding.

\subsection{Robustness checks}

To make sure the results are not driven by any critical economic events, we exclude the crisis years of 1997 and 1998. We show that for non-production workers, results 
Table 7 Minimum wages and average wages of production workers

\begin{tabular}{|c|c|c|c|c|c|c|}
\hline & \multicolumn{6}{|c|}{ Dependent variable: $\log ($ Real average wage of production workers) } \\
\hline & All Firms & All Firms & Small Firms & Small Firms & Large Firms & Large Firms \\
\hline \multirow[t]{2}{*}{ Log (Minimum Wage) } & $0.1060^{* * *}$ & $0.1537^{* * *}$ & $0.1317^{* * *}$ & $0.1844^{* * *}$ & 0.0607 & $0.0825^{*}$ \\
\hline & $(0.0190)$ & $(0.0226)$ & $(0.0217)$ & $(0.0260)$ & $(0.0391)$ & $(0.0473)$ \\
\hline \multirow[t]{2}{*}{ Log (Firm Age) } & & $0.1001^{* * *}$ & & $0.0960^{* * *}$ & & $0.1322^{* * *}$ \\
\hline & & $(0.0090)$ & & $(0.0104)$ & & $(0.0200)$ \\
\hline \multirow[t]{2}{*}{ Foreign Share } & & $0.0008^{* * *}$ & & $0.0013^{* * *}$ & & 0.0002 \\
\hline & & $(0.0003)$ & & $(0.0004)$ & & $(0.0004)$ \\
\hline \multirow[t]{2}{*}{ Export Share } & & -0.0000 & & 0.0000 & & 0.0001 \\
\hline & & $(0.0001)$ & & $(0.0001)$ & & $(0.0001)$ \\
\hline \multirow[t]{2}{*}{ Govt. Share } & & $0.0010^{* * *}$ & & $0.0015^{* * *}$ & & 0.0003 \\
\hline & & $(0.0002)$ & & $(0.0003)$ & & $(0.0004)$ \\
\hline Firm Fixed Effects & Yes & Yes & Yes & Yes & Yes & Yes \\
\hline Year Effects & Yes & Yes & Yes & Yes & Yes & Yes \\
\hline Observations & 233,442 & 159,959 & 170,667 & 115,569 & 62,775 & 44,390 \\
\hline Number of Firms & 32,388 & 30,941 & 27,855 & 26,269 & 8585 & 8295 \\
\hline R-squared & 0.6221 & 0.6558 & 0.6678 & 0.7044 & 0.5281 & 0.5926 \\
\hline
\end{tabular}

Notes: The sample includes only firms with non-zero production and non-production workers, firms that continuously observed from year to year, and firms observed more than once during the sample period. Small firms are firms which always have 150 or fewer workers; large firms are firms which always have more than 150 workers. The additional regressors have missing values in 2001, 2002, 2003, and 2005. Robust standard errors clustered by firm are reported in parentheses. ${ }^{* *} p<0.01,{ }^{* *} p<0.05,{ }^{*} p<0.1$

are consistent for different time periods within our sample. In the case of production workers, we find that the effect of the minimum wage on employment varies in terms of cyclical economic activity.

Table 9 shows the results of minimum wage changes on employment of paid production workers. Column (1) shows similar estimates to the main one (see Table 3). When the additional regressors are added in Column (2), the coefficient of the minimum wage remains significant and negative. Unlike the main results, the estimated elasticity for small firms is statistically significant and negative (see columns (3) and (4)). The effect of minimum wages on employment of production workers in large firms is statistically insignificant in both specifications when the sample of firms for 1997 and 1998 is dropped (see columns (5) and (6)). These results suggest that in large firms results are robust for the entire period. Similar to the main results, Table 10 reports the results of the effects of minimum wage changes on employment of paid non-production workers. The results for this group remain unchanged for the different samples.

Table 11 examines the robustness of our results to alternative definitions of small/ large firms. We use different cut-offs to define a small and large firm: 50, 100, 150, 200 and 300 employees respectively. In all specifications, the effect of the minimum wage on non-production employment in small firms is negative and significant. However, for large firms, the results are positive and becoming more significant when larger cut-offs are used. When the cut-offs of 50,100, and 150 are used, minimum wages have positive but statistically insignificant impacts on non-production workers. When the cut-offs of 200 and 300 are used, minimum wage changes significantly increase non-production employment. This is probably due to the substitutions from workers with junior high and high school education to workers with primary education (see Appendix). 
Table 8 Minimum wages and average wages of non-production workers

\begin{tabular}{|c|c|c|c|c|c|c|}
\hline & \multicolumn{6}{|c|}{ Dependent variable: Log(Real average wage of non-production workers) } \\
\hline & All Firms & All Firms & Small Firms & Small Firms & Large Firms & Large Firms \\
\hline \multirow[t]{2}{*}{ Log (Minimum Wage) } & $0.0600^{* *}$ & $0.1654^{* * *}$ & $0.0493^{*}$ & $0.1659^{* * *}$ & 0.0708 & $0.1186^{*}$ \\
\hline & $(0.0254)$ & $(0.0306)$ & $(0.0293)$ & $(0.0355)$ & $(0.0532)$ & $(0.0642)$ \\
\hline \multirow[t]{2}{*}{ Log (Firm Age) } & & $0.1015^{* * *}$ & & $0.0900^{* * *}$ & & $0.1183^{* * *}$ \\
\hline & & $(0.0120)$ & & $(0.0137)$ & & $(0.0283)$ \\
\hline \multirow[t]{2}{*}{ Foreign Share } & & $0.0023^{* * *}$ & & $0.0023^{* * *}$ & & $0.0020^{* * *}$ \\
\hline & & $(0.0004)$ & & $(0.0006)$ & & $(0.0005)$ \\
\hline \multirow[t]{2}{*}{ Export Share } & & $0.0004^{* * *}$ & & 0.0003 & & $0.0006^{* * *}$ \\
\hline & & $(0.0001)$ & & $(0.0002)$ & & $(0.0002)$ \\
\hline \multirow[t]{2}{*}{ Govt. Share } & & $0.0009^{* * *}$ & & $0.0012^{* * *}$ & & 0.0005 \\
\hline & & $(0.0003)$ & & $(0.0004)$ & & $(0.0005)$ \\
\hline Firm Fixed Effects & Yes & Yes & Yes & Yes & Yes & Yes \\
\hline Year Effects & Yes & Yes & Yes & Yes & Yes & Yes \\
\hline Observations & 226,507 & 158,153 & 163,898 & 113,839 & 62,609 & 44,314 \\
\hline Number of Firms & 31,798 & 30,112 & 27,253 & 25,434 & 8573 & 8286 \\
\hline R-squared & 0.6053 & 0.6405 & 0.6281 & 0.6767 & 0.5154 & 0.5571 \\
\hline
\end{tabular}

Notes: The sample includes only firms with non-zero production and non-production workers, firms that continuously observed from year to year, and firms observed more than once during the sample period. Small firms are firms which always have 150 or fewer workers; large firms are firms which always have more than 150 workers. The additional regressors have missing values in 2001, 2002, 2003, and 2005. Robust standard errors clustered by firm are reported in parentheses. ${ }^{* *} p<0.01,{ }^{* *} p<0.05,{ }^{*} p<0.1$

\subsection{Summary on the impacts of minimum wages on different groups}

Table 12 presents the effects of the minimum wage on employment of production and non-production workers by sex and education levels for small firms. As mentioned before, we concentrated in small firms because they are where the majority of the workforce is, and where there are interesting dynamics. The job losses are primarily driven by those among non-production workers. For every $10 \%$ increase in minimum wage, employment of non-production workers drops $0.78 \%$. And the vulnerability is much more accentuated for women than men. This result also has implications for workers in other sectors of the economy where the concentration of non-production workers is higher. Industries such as wholesale and retail and tourism in the services sector for example, have high concentration of (women) nonproduction workers with low levels of skill.

In addition, the importance of skill levels came through very clearly in the analysis, where less educated workers are hit hardest when minimum wage hikes take place. They are workers with primary, junior and senior high education. On the other hand, better skilled workers (with a high school education and above) are not affected. The underlying problem is that in the case of low-skilled (or unskilled) workers, higher minimum wage levels likely exceed their level of productivity. Thus, increases in the minimum wages mean that small firms, which are those that employ these workers most often and have low capital intensity, have to lay off non-essential workers. As better educated workers are not added in response to minimum wage increases, there is no evidence of substitutions between less educated and better educated workers. Instead, low skill workers are simply laid off by their employers. 
Table 9 Employment effects of minimum wages on production workers -restricted sample

\begin{tabular}{|c|c|c|c|c|c|c|}
\hline \multicolumn{7}{|c|}{ Dependent variable: Log (Number of paid production workers) } \\
\hline \multirow[b]{2}{*}{ VARIABLES } & \multicolumn{2}{|l|}{ All firms } & \multicolumn{2}{|c|}{ Small firms } & \multicolumn{2}{|c|}{ Large firms } \\
\hline & (1) & (2) & (3) & (4) & (5) & (6) \\
\hline \multirow[t]{2}{*}{ Log (Min. Wage) } & $-0.0436^{* * *}$ & $-0.0402^{* *}$ & $-0.0223^{*}$ & $-0.0315^{* *}$ & -0.0209 & 0.0125 \\
\hline & $(0.014)$ & $(0.017)$ & $(0.012)$ & $(0.015)$ & $(0.026)$ & $(0.032)$ \\
\hline \multirow[t]{2}{*}{ Log (Firm Age) } & & $0.195^{* * *}$ & & $0.0997^{* * *}$ & & $0.237^{* * *}$ \\
\hline & & $(0.007)$ & & $(0.006)$ & & $(0.015)$ \\
\hline \multirow[t]{2}{*}{ Foreign Share } & & $0.00175^{* * *}$ & & $0.000582^{* *}$ & & $0.00133^{* * *}$ \\
\hline & & $(0.000)$ & & $(0.000)$ & & $(0.000)$ \\
\hline \multirow[t]{2}{*}{ Export Share } & & $0.00115^{* * *}$ & & $0.000894^{* * *}$ & & $0.000469^{* * *}$ \\
\hline & & $(0.000)$ & & $(0.000)$ & & $(0.000)$ \\
\hline \multirow[t]{2}{*}{ Govt. Share } & & 0.000155 & & $5.42 \mathrm{E}-05$ & & $-2.49 \mathrm{E}-05$ \\
\hline & & $(0.000)$ & & $(0.000)$ & & $(0.000)$ \\
\hline Observations & 246,539 & 163,065 & 187,686 & 124,383 & 57,133 & 37,602 \\
\hline Number of Firms & 39,734 & 38,242 & 34,610 & 33,040 & 9119 & 8728 \\
\hline Fixed Effects & YES & YES & YES & YES & YES & YES \\
\hline Year Effects & YES & YES & YES & YES & YES & YES \\
\hline
\end{tabular}

Notes: This sample excludes observations for the years of the Asian financial crisis (1997 and 1998). Robust standard errors clustered by firm are reported in parentheses. ${ }^{* * *} p<0.01,{ }^{* *} p<0.05,{ }^{*} p<0.1$

\section{Conclusions}

This paper uses firm level data to investigate the employment and wage impacts of minimum wage changes in Indonesia, differentiating the effects on production workers and non-production workers, by educational category, and by gender profile. The use of firm level data allows the inclusion of firm fixed effects, which significantly reduces the extent of

Table 10 Employment effects of minimum wages on non-production workers -restricted sample

\begin{tabular}{|c|c|c|c|c|c|c|}
\hline \multicolumn{7}{|c|}{ Dependent variable: Log (Number of paid non-production workers) } \\
\hline & \multicolumn{2}{|l|}{ All firms } & \multicolumn{2}{|l|}{ Small firms } & \multicolumn{2}{|c|}{ Large firms } \\
\hline & (1) & (2) & (1) & (2) & (1) & (2) \\
\hline \multirow[t]{2}{*}{ Log (Min. Wage) } & $-0.0703^{* * *}$ & $-0.0402^{* *}$ & $-0.0717^{* * *}$ & $-0.0900^{* * *}$ & 0.00594 & 0.0563 \\
\hline & $(0.0205)$ & $(0.0165)$ & $(0.0213)$ & $(0.0269)$ & $(0.0404)$ & (0.0499) \\
\hline \multirow[t]{2}{*}{ Log (Firm Age) } & & $0.195^{* * *}$ & & $0.0990 * * *$ & & $0.264^{* * *}$ \\
\hline & & $(0.00712)$ & & $(0.0112)$ & & $(0.0228)$ \\
\hline \multirow[t]{2}{*}{ Foreign Share } & & $0.00175^{* * *}$ & & $0.00143^{* * *}$ & & $2.21 \mathrm{e}-05$ \\
\hline & & $(0.000225)$ & & $(0.000418)$ & & $(0.000436)$ \\
\hline \multirow[t]{2}{*}{ Export Share } & & $0.00115^{* * *}$ & & $0.000785^{* * *}$ & & $0.000334^{*}$ \\
\hline & & $(9.35 e-05)$ & & $(0.000177)$ & & (0.000183) \\
\hline \multirow[t]{2}{*}{ Govt. Share } & & 0.000155 & & $0.000592^{* *}$ & & 0.000390 \\
\hline & & $(0.000173)$ & & $(0.000246)$ & & $(0.000437)$ \\
\hline Observations & 211,617 & 163,065 & 154,936 & 97,313 & 55,189 & 36,372 \\
\hline Number of Firms & 36,440 & 38,242 & 31,234 & 28,812 & 8989 & 8593 \\
\hline Fixed Effects & YES & YES & YES & YES & YES & YES \\
\hline Year Effects & YES & YES & YES & YES & YES & YES \\
\hline
\end{tabular}

Notes: This sample excludes observations for the years of the Asian financial crisis (1997 and 1998). Robust standard errors clustered by firm are reported in parentheses. ${ }^{* * *} p<0.01,{ }^{* *} p<0.05,{ }^{*} p<0.1$ 
Table 11 Employment effects of minimum wages on non-production workers using different cut-offs for the definition of small/large firms

\begin{tabular}{|c|c|c|c|c|c|c|c|c|c|c|}
\hline & \multicolumn{2}{|l|}{$n=50$} & \multicolumn{2}{|l|}{$n=100$} & \multicolumn{2}{|l|}{$n=150$} & \multicolumn{2}{|l|}{$n=200$} & \multicolumn{2}{|l|}{$n=300$} \\
\hline & (1) & (2) & (3) & (4) & (5) & (6) & (7) & (8) & (9) & (10) \\
\hline & Small $(<50)$ & Large (>50) & Small $(<100)$ & Large $(>100)$ & Small $(<150)$ & Large (>150) & Small $(<200)$ & Large $(>200)$ & Small $(<300)$ & Large $(>300)$ \\
\hline \multirow[t]{2}{*}{ Log (Minimum Wage) } & $-0.0909^{* * *}$ & 0.0117 & $-0.0873^{* * *}$ & 0.0358 & $-0.0778^{* * *}$ & 0.0635 & $-0.0888^{* * *}$ & $0.147^{* * *}$ & $-0.0770^{* * *}$ & $0.174^{* * *}$ \\
\hline & $(0.0319)$ & $(0.0350)$ & $(0.0276)$ & $(0.0431)$ & $(0.0262)$ & $(0.0494)$ & $(0.0257)$ & $(0.0533)$ & $(0.0252)$ & $(0.0635)$ \\
\hline Observations & 76,645 & 90,494 & 107,784 & 60,291 & 122,599 & 45,671 & 131,424 & 36,958 & 142,011 & 26,500 \\
\hline R-squared & 0.005 & 0.015 & 0.007 & 0.013 & 0.008 & 0.013 & 0.009 & 0.013 & 0.010 & 0.012 \\
\hline Number of plant_id & 22,043 & 17,789 & 27,199 & 11,542 & 29,419 & 8772 & 30,604 & 7191 & 31,891 & 5273 \\
\hline Fixed Effects & Yes & Yes & Yes & Yes & Yes & Yes & Yes & Yes & Yes & Yes \\
\hline Year Effects & Yes & Yes & Yes & Yes & Yes & Yes & Yes & Yes & Yes & Yes \\
\hline
\end{tabular}

Robust standard errors in parentheses

${ }^{* * *} p<0.01, * * p<0.05,{ }^{*} p<0.1$ 
Table 12 Employment effects of minimum wages on non-production workers and production workers by sex and education levels-small firms

\begin{tabular}{lll}
\hline & Production workers & Non-production workers \\
\hline Male & -0.0208 & -0.029 \\
& $(0.021)$ & $(0.029)$ \\
Female & -0.043 & $-0.0692^{* *}$ \\
& $(0.031)$ & $(0.029)$ \\
Primary & -0.0855 & $-0.2915^{*}$ \\
& $(0.072)$ & $(0.166)$ \\
Jr. Sr. High & $-0.1957^{* * *}$ & $-0.1553^{* * *}$ \\
& $(0.055)$ & $(0.050)$ \\
High School & 0.0233 & -0.0751 \\
& $(0.216)$ & $(0.111)$ \\
Bachelor & 0.0891 & -0.049 \\
All & $(0.198)$ & $(0.103)$ \\
& $-0.0265^{*}$ & $-0.0779^{* * *}$ \\
& $(0.015)$ & $(0.026)$
\end{tabular}

${ }^{*}$ significant at $1 \%$ level; ${ }^{* *}$ significant at $5 \%$ level; ${ }^{* * *}$ significant at $10 \%$ level

endogeneity bias. The analysis focuses on understanding the effects in the manufacturing sector, which constitutes a significant formal component of the Indonesian labor force.

The paper finds that in the manufacturing sector, minimum wages have negative employment effects on small firms but not on large firms. Since there are many more small firms, the aggregate effect of the minimum wages is to have an overall negative effect on formal employment, i.e. they lead to losses of formal jobs. The negative effects are largely concentrated among labor intensive firms with unskilled or less skilled workers. This finding has implications beyond the manufacturing sector, especially because Indonesia, like many developing economies, has a large concentration of lowskilled workers employed in small firms. Thus, sharp raises of the minimum wages could prevent job creation and retention, and a reduction in formal employment. As shown in other countries, increases in the minimum wages without commensurate raises in worker productivity levels can lead to unemployment or increase informality among low-skill workers. Nonetheless, the negative effects of minimum wage changes on employment are much smaller than previous estimates.

Minimum wages are also found to be correlated with firms' average wages. They are more correlated with average wages in small firms than in large firms, which suggests that minimum wages are significantly more binding for small firms who on average pay workers less than large firms do.

The results of the paper indicate that assistance to vulnerable groups is necessary when minimum wage increases are implemented. In the Indonesian context they are low-skilled, female and non-production workers: they tend to lose jobs in manufacturing when minimum wages are raised. While we acknowledge that minimum wage increases might boost social welfare (from increased income and hence consumption of workers who retain jobs) and improve productivity, the fact that we find vulnerable groups calls for assistance programs to help them during the unemployment period. The assistance includes providing unemployment benefits, training and assisting the laid-off in their job search. 


\section{Appendix A}

Table 13 Number of observations

\begin{tabular}{ll}
\hline Group of workers & Number of observations \\
\hline Female production workers & $21,700,000$ \\
Male production workers & $21,900,000$ \\
Female non production workers & $2,468,865$ \\
Male non production workers & $5,966,800$ \\
Small firms & $10,305,766$ \\
Large firms & $41,542,850$ \\
Production workers & $43,600,000$ \\
Non production workers & $8,435,635$
\end{tabular}

Source: Indonesia Industry Survey (SI)

Table 14 Descriptive statistics

\begin{tabular}{llllll}
\hline Meaning & Obs & Mean & Std. Dev. & Min & Max \\
\hline Log of total paid employment & 290334 & 4.208 & 1.192 & 0 & 9.5490 \\
Log of total paid production employment & 290248 & 4.020 & 1.191 & 0 & 9.3923 \\
Log of total paid non-production employment & 246081 & 2.279 & 1.455 & 0 & 8.5553 \\
Log of real minimum wage & 290339 & 4.485 & 0.264 & 3.689 & 5.1684 \\
Log of firm age & 289654 & 2.354 & 0.854 & 0 & 4.6052 \\
Log of percentage exported & 207256 & 10.725 & 28.488 & 0 & 100 \\
Percentage owned by foreigners & 290339 & 5.652 & 21.227 & 0 & 100 \\
Percentage owned by government & 290339 & 2.798 & 15.995 & 0 & 100 \\
Log of real value added per worker & 289806 & 8.103 & 1.3196 & -3.9571 & 16.518 \\
Log of real average wage per production worker & 290149 & 7.059 & 0.857 & -2.255 & 15.239 \\
Log of real average wage per non-production worker & 238725 & 7.631 & 1.075 & -6.688 & 16.194 \\
\hline
\end{tabular}

Table 15 Employment effects of minimum wages on production workers in large firms by educational category

\begin{tabular}{|c|c|c|c|c|}
\hline & \multicolumn{4}{|c|}{ Dependent variable: Log (Employment of production workers) } \\
\hline & Primary & Jr. Sr. High & High School & Bachelor \\
\hline \multirow[t]{2}{*}{ Log (Min. Wage) } & -0.001 & 0.023 & -0.184 & -0.114 \\
\hline & $-(0.138)$ & $-(0.067)$ & $-(0.147)$ & $-(0.143)$ \\
\hline \multirow[t]{2}{*}{ Log (Firm Age) } & $0.139^{* *}$ & $0.165^{* * *}$ & -0.027 & -0.085 \\
\hline & $-(0.062)$ & $-(0.029)$ & $-(0.070)$ & $-(0.065)$ \\
\hline \multirow[t]{2}{*}{ Foreign Share } & 0.000 & $0.00152^{* * *}$ & 0.001 & $0.00179 *$ \\
\hline & $-(0.001)$ & $(0.000)$ & $-(0.001)$ & $-(0.001)$ \\
\hline \multirow[t]{2}{*}{ Export Share } & 0.000 & $0.000587^{* * *}$ & 0.001 & 0.000 \\
\hline & $(0.000)$ & $(0.000)$ & $-(0.001)$ & $-(0.001)$ \\
\hline \multirow[t]{2}{*}{ Govt. Share } & 0.001 & 0.000 & 0.001 & 0.000 \\
\hline & $-(0.001)$ & $-(0.001)$ & $-(0.001)$ & $-(0.001)$ \\
\hline Firm Fixed Effects & Yes & Yes & Yes & Yes \\
\hline Year Effects & Yes & Yes & Yes & Yes \\
\hline Number of Firms & 16,360 & 19,036 & 3592 & 3087 \\
\hline Observations & 35,634 & 40,865 & 5159 & 4502 \\
\hline
\end{tabular}

${ }^{*}$ significant at $1 \%$ level; ${ }^{* *}$ significant at $5 \%$ level; ${ }^{* * *}$ significant at $10 \%$ level 
Table 16 Employment effects of minimum wages on non-production workers in large firms by educational category

\begin{tabular}{lllll}
\hline & \multicolumn{4}{l}{ Dependent variable: Log (Employment of non-production workers) } \\
\cline { 2 - 5 } & Primary & Jr. Sr. High & High School & Bachelor \\
\hline Log (Min. Wage) & $0.511^{*}$ & $-0.196^{* * *}$ & $-0.328^{* * *}$ & 0.122 \\
& $-(0.268)$ & $-(0.061)$ & $-(0.107)$ & $-(0.095)$ \\
Log (Firm Age) & $0.195^{*}$ & $0.188^{* * *}$ & $0.0872^{*}$ & -0.0208 \\
Foreign Share & $-(0.117)$ & $-(0.028)$ & $-(0.045)$ & $-(0.041)$ \\
& 0.00109 & 0.000228 & 0.000892 & $0.00198^{* * *}$ \\
Export Share & $-(0.001)$ & $(0.000)$ & $-(0.001)$ & $-(0.001)$ \\
& $-0.00128^{* *}$ & $0.00111^{* * *}$ & 0.0004 & $0.00105^{* * *}$ \\
Govt. Share & $-(0.001)$ & $(0.000)$ & $(0.000)$ & $(0.000)$ \\
& 0.0007 & 0.0003 & -0.0006 & -0.0006 \\
Firm Fixed Effects & $-(0.001)$ & $-(0.001)$ & $-(0.001)$ & $-(0.001)$ \\
Year Effects & Yes & Yes & Yes & Yes \\
Number of Firms & 3839 & Yes & Yes & Yes \\
Observations & 7914 & 7128 & 5891 & 6073 \\
\hline
\end{tabular}

${ }^{*}$ significant at $1 \%$ level; ${ }^{* *}$ significant at $5 \%$ level; ${ }^{* * *}$ significant at $10 \%$ level

\section{Appendix B: Definitions of variables}

Firm level data: The explanatory variable of interest is log of real minimum wage (Minimum wage). Other control variables are log of firm's age (Firm age), percentage owned by foreigners (Foreign), percentage of output exported (Export), percentage owned by local and central government (Government), and log of real value added per worker (Value Added).

Export: percentage of a firm's output that is exported.

Foreign: percentage of firms owned by foreigners.

Government: percentage of firms owned by local or central government.

Value added: $\log$ of real value added per worker. This is calculated by taking value added per worker divided by the provincial CPI obtained from the BPS.

Minimum wages: Minimum wages were obtained from BPS as monthly provincial minimum wages (or averages where there is within-province variation across districts) for each year. Real minimum wages are obtained by deflating provincial minimum wages by the provincial CPI. We are grateful to Bob Rijkers and Mary HallwardDriemeier and David Newhouse for making the data available to us.

Wages (firm level averages): following Hallward-Driemeier et al. (2010), wages are defined as the average wages for production and non-production workers, constructed as the total wage bill for either group divided by the number of workers of either respective group. The total wage bill for production and non-production workers is defined as the sum of cash wages and in-kind benefits.

Production workers: Production workers, defined by Indonesia industry survey, as "workers who work directly in the production process, or activities connected with the production process, from the time materials enter the factory until the final products are sent out of the factory, for example, foreman supervising the production process, driver of a forklift in the factory, workers of working in the processing of goods etc.". 


\section{Endnotes}

${ }^{1}$ Production workers, defined by Indonesia industry survey, as "workers who work directly in the production process, or activities connected with the production process, from the time materials enter the factory until the final products are sent out of the factory, for example, foreman supervising the production process, driver of a forklift in the factory, workers of working in the processing of goods etc.".

${ }^{2}$ See Neumark and Wascher (2008) for a comprehensive overview.

${ }^{3}$ An exception is Indonesia Jobs Report (2010) where they analyze employment using individual level data, rather than provincial aggregates in province fixed effects regressions. They also find that minimum wages tend to decrease industrial and formal sector employment.

${ }^{4}$ Similar evidence is also found for Indonesia, see Indonesia Jobs report, by the World Bank 2010.

${ }^{5}$ Law on Manpower Affairs 2003 articles 88 and 89. Regulation regarding implementation and component of achievement scale on adequate living needs (ALN) articles1 and 3. cited in ILO (2011a).

${ }^{6}$ Please see the Appendix for the sources of minimum wage data.

${ }^{7}$ It is worth noting that the minimum wage in China has been increasing rapidly in recent years and the ratio may be the same or higher than Indonesia in 2012.

${ }^{8}$ The SI data track establishments, rather than firms. A recent PBS study has suggested that less than 5\% of establishments in the Manufacturing Census are owned by a multi-establishment firm (see Hallward-Driemeier et al., 2010 for a discussion). For this reason, we will use the terms "firms" and "plants" interchangeably throughout the paper.

${ }^{9}$ Since we utilize panel data with firm fixed effects, we drop firms that appear only once during the sampled period.

${ }^{10}$ Domestic firms are defined as those that have $10 \%$ or less owned by foreigners.

${ }^{11}$ Labor-intensive manufacturing firms are defined as firms in textiles, leather, footwear, wood products and furniture.

${ }^{12}$ Some provinces were split during the sample period. We allow minimum wages to differ across the split provinces.

${ }^{13}$ The sample size is smaller when additional regressors are added as these variables have missing values for several years.

${ }^{14}$ Figure 8 is estimated using a kernel density method on a weighted sample. The vertical line represents an average of all sub-national minimum wage lines (logged) in the country. There are about 28 different lines, and these range from as low as 12.87 in East Java to as high as 13.62 in West Irian Jaya, Aceh and Jakarta.

${ }^{15}$ Data on education of the workforce is available only in four years: 1995, 1996, 1997 and 2006.

${ }^{16}$ Evidence from around the world shows that firms factor in costs associated with benefits they provide women (e.g. maternity and family leave, maternity insurance coverage). They also factor costs for replacing women during longer work absences (Ruhm, 1998). 


\section{Acknowledgement}

This work is a part of a broader study conducted by the Social Protection and Labor Global Practice of the World Bank to investigate the impacts of minimum wage policies in ASEAN countries. We are grateful for financial support and encouragement from the SPL Global Practice, DEC Research Budget and the ASEAN secretariat. We are grateful to Mary Hallward-Driemeier, David Newhouse and Bob Rijkers for kindly sharing the data. We thank Asli Demirguc-Kunt, Ha Le, Norman Loayza, William Maloney, David Newhouse, Rong Qian, Martin Rama, Bob Rijkers, Luis Serven, Rizal Shidiq, Trang Tran and participants at the World Bank's FPD Academy seminar for their comments and feedback, and Kate Daley for able research assistance. All errors are our own.

Responsible editors: Haroon Bhorat, Ravi Kanbur and Li Shi

\section{Author details}

${ }^{1}$ Social Protection and Labor Global Practice of the World Bank, Melbourne, Australia. ${ }^{2}$ Development Research Group (DEC) of the World Bank, Melbourne, Australia. ${ }^{3}$ Monash University, Melbourne, Australia.

Received: 5 March 2015 Accepted: 28 September 2015

Published online: 29 October 2015

\section{References}

Alatas V, Cameron L (2008) "The impact of minimum wages on employment in a low income country: a Quasi-natural experiment in Indonesia". Ind Labor Relat Rev 61(2):201-223

Bell L (1997) "The impact of minimum wages in Mexico and Colombia". J Labor Econ 15(3):102-135

Burkhauser R, Couch K, Wittenburg D (2000) "A reassessment of the new economics of the minimum wage literature with monthly data from the current population survey". J Labor Econ 18(4):653-680

Card D, Krueger A (1994) Minimum wages and employment: a case study of the fast-food industry in New Jersey and Pennsylvania. Am Econ Rev 84(4):772-793

Comola M, de Mello L (2011) "How does decentralized minimum wage setting affect employment and informality? The case of Indonesia". Rev Income Wealth 57:79-99

Cuevas S, Mina C, Barcenas M, Rosario A (2009) "Informal Employment in Indonesia". Asian Development Bank, ADB Economics Working Paper Series, Manila, p 156

Dube A, William Lester T, Michael R (2010) "Minimum wage effects across state borders: estimates using contiguous counties". Review of Economics and Statistics 92(4):945-964

Gindling T, Terrell K (2007) "The effects of multiple minimum wages throughout the labour market: the case of Costa Rica". Labour Economics, Elsevier 14(3):485-511

Harrison A, Scorse J (2010) Multinationals and anti-sweatshop activism. Am Econ Rev 100(1):247-273

Hallward-Driemeier M and Rijkers B and Waxman A (2010) "Can minimum wages close the gender wage gap? Evidence from Indonesia", mimeo, The World Bank, Washington, DC

Hausmann R, Tyson LD, Zahidi S (2010) "The Global Gender Gap Report 2010". World Economic Forum, Geneva, Switzerland

Islam I, Nazara S (2000) "Minimum Wage and the Welfare of Indonesian Workers". Occasional Discussion Papers, ILO Jakarta Office

Katz L (1987) Efficiency wage theories: a partial evaluation. In: Fischer S (ed) NBER Macroeconomics Annual. MIT Press, Cambridge, MA

Katz $L$ and Krueger A (1992) "The Effect of the Minimum Wage on the Fastfood Industry". Industrial and Labor Relations Review 46:6-21.

Kristensen N and Cunningham W (2006) "Do Minimum Wages in Latin America and the Caribbean Matter? Evidence from 19 Countries", The World Bank Research Working Paper Series, WPS3870, Washington, DC

Levine D (1992) "Can wage increases pay for themselves? Tests with a productive function". Economic Journal 102(414):1102-1115

Loayza N, Oviedo AM, Servén L (2005) "The Impact of Regulation on Growth and Informality". World Bank Policy Research Working Paper Series 3623, Washington, DC

Magruder J (2011) "Can Minimum Wages Cause a Big Push? Evidence from Indonesia" mimeo, University of Berkley, Berkeley, CA

Maloney, W. and J. Nunez (2004), "Minimum Wages in Latin America", in Law and Employment: Lessons from Latin America and the Caribbean, by J. Heckman and C. Pag_Es (eds.), The University of Chicago Press, Cambridge, MA.

Miranda V (2011), "Cooking, Caring and Volunteering: Unpaid Work Around the World", OECD Social, Employment and Migration Working Papers, No. 116, OECD Publishing. http://www.oecd.org/berlin/47258230.pdf

Neumark D and Wascher W (2000) "Minimum Wages and Employment: A Case Study of the Fast-Food Industry in New Jersey and Pennsylvania: Comment." American Economic Review, 90(5):1362-1396.

Neumark D, Wascher W (2008) "Minimum Wages", The MIT Press

Neumark D, lan Salas JM, Wascher W (2014) Revisiting the minimum wage-employment debate: throwing out the baby with the bathwater? Ind Labor Relat Rev 67(3):608-648

Neumark D, lan Salas JM, William W (2015) "More on recent rvidence on the effects of Minimum Wages in the United States" NBER Working paper No. 20619

Nguyen VC (2010), "The Impact of a Minimum Wage Increase on Employment, Wages and Expenditures of Low-Wage Workers in Vietnam". Munich Personal RePEC Archive (MPRA) No. 36751, Washington, DC

Perry GE, Maloney WF, Arias O, Fajnzylber P, Mason AD, Saavedra-Chanduvi J (2007) Informality: Exit and exclusion. Washington, DC, World Bank.

Pratomo D (2011) "The Effects of Changes in Minimum Wage on Employment in Indonesia: Regional Panel Data Analysis". International Research Journal of Finance and Economics 62:15

Priebe J (2010) "Child Costs and the Causal Effect of Fertility on Female Labor Supply: An investigation for Indonesia 1993-2008". Center for Statistics and Department of Economics working paper, University of Gottingen 
Rama M (2001) "The consequences of doubling the minimum wage: the case of Indonesia". Ind Labor Relat Rev 54(4):864-881

Raff D, Summers L (1987) "Did Henry ford pay efficiency wages?". J Labor Econ 5(4):S57-S86

Rebitzer J, Taylor L (1995) The consequences of minimum wage laws: some new theoretical ideas. J Public Econ $56: 245-255$

Ruhm C (1998) The economic consequences of parental leave mandates: lessons from Europe. Q J Econ 113(1):285-317

Suryahadi A, Widyanti W, Perwira D, Sumarto S (2001) "The impact of minimum wage policy on wages and

employment in developing countries". East-west center working paper. economi series no. 30. December 2001. Honolulu, Hawai.

Suryahadi A, Widyanti W, Perwira D, Sumarto S (2003) "Minimum wage policy and its impact on employment in the urban formal sector". Bull Indones Econ Stud 39(1):29-50

World Bank (2010) Indonesia Jobs Report. The World Bank, Jakarta

\section{Submit your manuscript to a SpringerOpen ${ }^{\circ}$ journal and benefit from:}

- Convenient online submission

- Rigorous peer review

- Immediate publication on acceptance

- Open access: articles freely available online

- High visibility within the field

- Retaining the copyright to your article

Submit your next manuscript at $\boldsymbol{\nabla}$ springeropen.com 